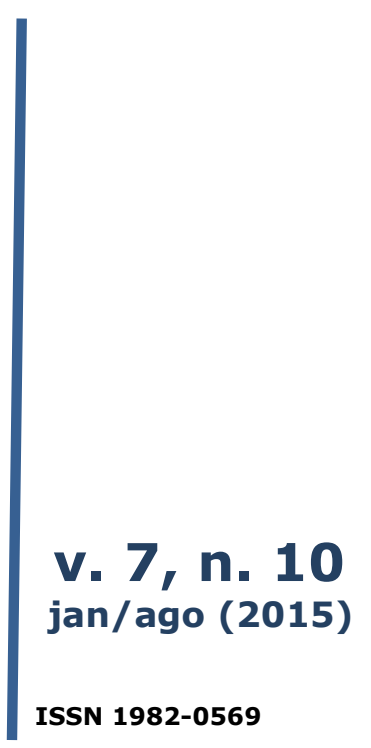

\section{A CENOGRAFIA E O ESPAÇO-TEMPO NO NEORREALISMO COMO INDICADOR DA SOCIEDADE ITALIANA NO PÓS-GUERRA uma breve análise a partir de Roma, Cidade Aberta e Ladrões de Bicicleta}

\section{SCENERY AND SPACE-TIME RELATION IN NEOREALISM AS AN INDICATOR OF POST-WAR \\ ITALIAN SOCIETY \\ An analysis of roma Città Aperta and Ladri di Biciclette}

Renata Latuf de Oliveira Sanchez Universidade Estadual de Campinas - UNICAMP e-mail: renata los@hotmail.com

\begin{abstract}
Resumo
As relações entre as diversas produções artísticas ao longo dos anos mostram-se relevantes para o entendimento de um contexto histórico e seu retrato político, social, psicológico. Entendemos que a arquitetura é capaz de moldar uma sociedade e, com sedimentos temporais, revelar informações cruciais do espaço habitado, constantemente formado e transformado. O cinema, por sua vez, capta as emoções e o movimento da realidade pelos olhos de um ser sensível, tornando-se precioso documento histórico e objeto estético. Este artigo discute a relação entre Arquitetura e Cinema a partir do neorrealismo italiano e sua representação do espaço urbano na década de 1940, através de uma análise dual entre as obras Roma, Cidade Aberta (1945), de Rosselini, e Ladrões de Bicicleta (1948), de De Sica.
\end{abstract}

\section{Palavras-Chave}

Neorrealismo Italiano. Arquitetura. Espaço Urbano

\begin{abstract}
The relations between the different artistic manifestations in the past years have proved themselves extremely relevant for the understanding of a historical context and its political, social and psychological portrait. We think that architecture, as a basic art, can build society, and with its temporal sediments can reveal crucial information about the living space, continuously formed and transformed. Cinema, on the other hand, captures the emotions and movement of reality through the eyes of a sensitive human being, the director, becoming, therefore, a precious historical document and aesthetical object. Here we intend to relate Cinema and Architecture, based on a discussion about neorealism and the urban space in Italy in the 1940s, analysing Rome: Città Aperta (1945) and Ladri di Bicicletti (1948).
\end{abstract}

\section{Keywords}

Italian Neorealism. Architecture. Urban Space 


\section{Introdução}

As consequências decorrentes do fim da $2^{a}$ Guerra Mundial foram vistas em diversos aspectos em toda a Europa: social, político, econômico, cultural. O fracasso dos regimes totalitários e a completa destruição de nações (física e espiritualmente) foram campo para o florescimento de muitos movimentos contracorrente que procuravam rever os cânones sobre os quais a sociedade havia se baseado até então, numa resistência a modelos preestabelecidos nas décadas anteriores, que pareciam não ter mais sentido após esse grande episódio na história da humanidade.

No campo cultural, precisamente no campo das artes, muitas manifestações foram concretizadas em resposta aos efeitos aniquiladores da sociedade e na busca pela arte engajada, de crítica social. Assistia-se a exemplos como o Abstracionismo e Novo Realismo nas artes plásticas (dentre os representantes do primeiro destaca-se o trabalho de Francis Bacon - ver Figura 1) o Neorrealismo Italiano no cinema, uma reformulação conceitual dos modelos construtivos na Arquitetura, que se opunham à rigidez do Movimento Moderno e criavam espaço a uma "pós-modernidade". Um novo modelo de sociedade e espaço parecia surgir, exigindo espírito crítico para as mudanças e nova dinâmica, ao mesmo tempo em que se percebia difícil a esperança em meio ao caos ocasionado pela guerra e suas consequências.
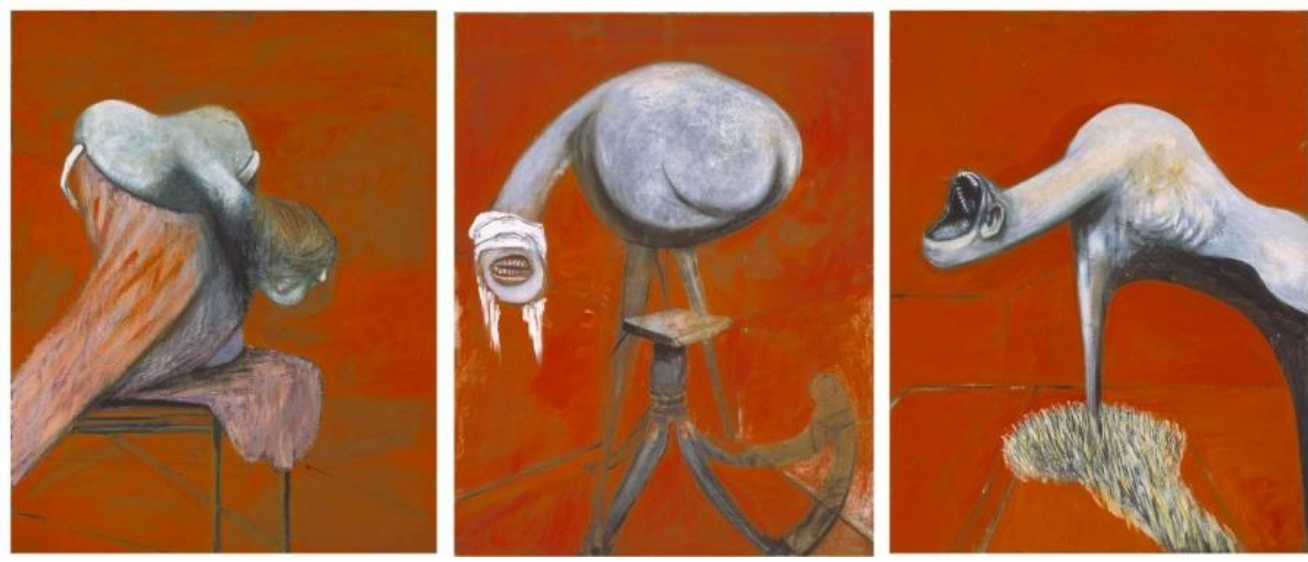
Figura 1: Francis Bacon. "Three Studies for Figures at the Base of a Crucifixion" (1944).

Original em Cor. Exibido em Londres pela primeira vez em abril de 1945, o último mês da $2^{a}$ Guerra Mundial. Nesse mês, o público britânico ouviu pela primeira vez sobre os horrores cometidos nos campos de concentração nazistas, quando foi transmitido na BBC Radio reportagem de Richard Dimbleby sobre a liberação de Belsen. O quadro trouxe a Bacon grande reputação, cuja imagem passou a ser associada à repulsa completa pela desumanidade do século XX. Um crítico descreveu uma outra obra de Bacon, a "Second Version of Triptych 1944" como reflexo do "mundo de atrocidades ao qual sobrevivemos"1.

Como objeto de estudo deste texto, pretende-se abordar o Neorrealismo Italiano, enquanto estética cinematográfica, em consonância com discussões a respeito do Espaço Urbano, a partir da ótica da Arquitetura e de estudos da Sociologia sobre o fenômeno urbano a partir da modernidade. Para tanto, foram selecionados dois filmes emblemáticos do neorrealismo italiano da década de 1940: Roma, Cidade Aberta, de 1945, de Roberto Rosselini, e Ladrões de Bicicleta, de 1948, de Vittorio de Sica.

O primeiro retrata a resistência ao fascismo, representada nas personagens Giorgio Manfredi (Marcello Pagliero), Francesco (Francesco Grandjacquet), Pina (Anna Magnani) e Don Pietro (Aldo Fabrizi). Manfredi, um guerrilheiro comunista procurado pelos nazistas, precisa entregar um milhão de liras a seus compatriotas e, para tanto, refugia-se no apartamento de Francesco, noivo de Pina, para a qual pede ajuda. Francesco pretende que Don Pietro, um padre católico, entregue o dinheiro. O filme se passa, em boa parte, em cenas internas do apartamento de Pina, e mostra, além disso a dura vida da classe operária neste período. Entretanto, o edifício de Pina é eventualmente cercado pelos nazistas, que acabam levando Francesco para um caminhão. Em um ato de desespero, Pina corre atrás do mesmo e é metralhada, uma das cenas mais

\footnotetext{
${ }^{1}$ Imagem parte da coleção disponível para consulta online do Tate Museum, em Londres, com descrição da obra e transcrição do audioguide fornecido pelo Museu. Em: http: / /www.tate.org.uk/art/artworks/bacon-three-studies-for-figures-at-the-base-of-acrucifixion-n0617. Para a outra obra citada: http://www.tate.org.uk/art/artworks/baconsecond-version-of-triptych-1944-t05858
} 
duras de todo o filme, em que a morte, entretanto, é desprovida de qualquer sentimentalismo. Manfredi procura, então, sua amante, a inescrupulosa cantora Marina, que durante o filme revela seu caráter trocando sua adesão ao nazismo por casacos de pele e drogas. Sem saber disso, comete um grande erro, pois é então delatado por sua companheira. Com Manfredi e Don Pietro capturados, revela-se o aspecto mais expressivo dessas personagens imbuídas de coragem e escrúpulo, até mesmo sob forte tortura, em momentos finais da história.

No segundo, a realidade seca e a dose quase escassa de sentimentalismo dão lugar a uma narrativa um pouco mais "humanista", por Vittorio de Sica. A história, também em Roma, relata a saga de Antonio Ricci (Lamberto Maggiorani), trabalhador humilde recém contratado para colar cartazes, para recuperar sua bicicleta, roubada durante um de seus expedientes e necessária para que continue a exercer sua atividade. Com a ajuda do filho, Bruno (Enzo Staiola), sai em busca da bicicleta pelas ruas de Roma, objeto que se torna, durante a procura, metáfora para a busca pela dignidade e reinserção à vida social e urbana, dilacerada pelo caos da guerra. A relação entre pai e filho também é explorada durante a trama, na qual a cidade desempenha papel de personagem.

O Neorrealismo italiano, comumente lembrado pela tríade de diretores Roberto Rosselini - Vittorio De Sica/Cesare Zavattini - Luchino Visconti, foi o marco de uma resistência no campo cinematográfico ao modo tradicional de se filmar, em especial contra a estética hollywoodiana e a de propaganda (como havia sido feito com os filmes fascistas italianos no final da década de 1930). Sua estética antiespetacular, com uma mise-en-scène elaborada a fim de representar a realidade em seus detalhes mais sutis, marcou a sétima arte para sempre, e tem como cenário corrente para o desenrolar de suas histórias o ambiente real do pós-guerra, bem como os problemas sociais neste existentes.

Entretanto, mais do que uma escolha, o modo de filmar no neorrealismo é decorrente também da realidade dos próprios cineastas e do estado de indignação partilhado pelos mesmos. Rosselini, na época em que filmou Roma

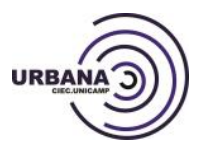


Cidade Aberta, estava sem fundos para produzir, e dependia de mecenas que também estavam falidos. A ausência dos estúdios também foi um dos fatores que levou uma série de cineastas para as ruas, que viram, ali, um campo fecundo para explorar suas ideias e posicionamentos, em forte questionamento à situação social vigente.

Apesar de cenário onipresente para os cineastas, a cidade recebe pelos diretores tratamento calculado, visando enfatizar o caráter de "realidade" que se desejava atingir. Segundo Stefania Parigi em Le carte d'identità del neorealismo (apud Augusto, 2005), "a realidade no cinema é sempre um efeito da representação da realidade, a consequência de uma estratégia de mise en scène, o resultado de um aparato de mediações e ficções". Assim, a construção do "real" é fruto de um trabalho cuidadoso sobre o aparato fílmico, que não simplesmente grava cegamente o entorno, mas resulta de uma seleção e trabalho profundamente pensados em torno dos materiais da representação.

Outra característica importante na estética neorrealista é o tratamento reducionista na filmagem: quanto menores os fatos, mais cotidianos, quanto mais humildes os protagonistas, quanto menos eventos, quanto mais simples for o aparato usado para filmá-los e quanto mais rápido eles forem reproduzidos, o mais perto se está da "realidade" (Wagstaff, 2007, p.84). Roma, Cidade Aberta é um exemplo disso, na medida em que relata fragmentos de histórias cuidadosamente escolhidos dentro de um fato histórico.

Com cenas filmadas in loco, em locais devastados por bombas, transformados em ruínas, ou paisagens de uma urbanidade perdida, assim como a esperança e civilidade de seus habitantes, o cinema neorrealista se impôs como crítica social e denúncia de uma realidade que a estética tradicional fílmica não mostraria. A presença de atores não profissionais e "não-atores", a filmagem longe dos estúdios (contando com fatores particulares, como luz natural), a espontaneidade e veracidade dos cenários exibidos, a preocupação com um retrato do cotidiano, a impressão do tempo com a duração que ele tem fora das

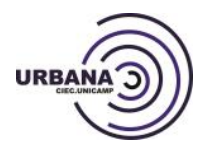


telas, são marcas importantes para a história do cinema e constituem-se em referência para muitos movimentos anti-mainstream posteriores.

Aqui se deseja, antes de tudo, salientar tais cenários reais, pura arquitetura, como retratos fieis do espaço urbano italiano na época, além de expressivo documento histórico e arquitetônico. As relações entre o espaço, arquitetura e sociedade presentes nos filmes são um dos papeis principais no Neorrealismo, que estabelece, assim, um diálogo muito recorrente entre Cinema e Arquitetura, através da cenografia e fotografia, com a relação que se estabelece entre personagem, tempo e espaço.

"Roma, Cidade Aberta" não é apenas um marco na história do cinema italiano, mas, provavelmente, com "Ladrões de Bicicleta", de De Sica, um dos mais influentes e simbólicos filmes de sua época, um filme sobre a "realidade" que deixou uma marca em cada movimento cinematográfico que veio depois. É também a história de uma atípica e fascinante aventura de filmar, uma obraprima involuntária, um caso único de cinema que resultou, em certo sentido, da sorte. (Ingrid Bignardi, Criterion Collection, apud Carlos, 2011, p.32)

\section{Algumas reflexões sobre o Espaço Urbano e o Tempo em Roma, Cidade Aberta e Ladrões de Bicicleta}

O ponto de partida de Roma, Cidade Aberta é a cidade de Roma vista por um ângulo alto, apreendida em um movimento de câmera contínuo horizontal para a esquerda, que delineia um skyline da cidade, onde se podem avistar marcos arquitetônicos importantes, cúpulas e torres de igrejas, além da arquitetura vernacular (vista através dos telhados) dos muitos edifícios que compõe tal cidade (ver Figura 2).

O cenário que abre e fecha o filme é o de Roma, com a cúpula da Basílica de São Pedro ao centro, vista de ângulos opostos. Essa imagem colocada nos dois extremos da história reafirma que a cidade é uma personagem que se

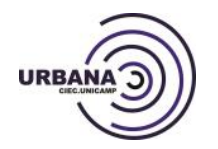

REVISTA ELETRONICA DO CENTRO INTERDISCIPLINAR DE ESTUDOS SOBRE A CIDADE . ISSN 1982-0569 v. 7, n. 10, jan /ago (2015). Dossiê História Urbana: a configuração de um campo conceitual 
sobrepõe à ficção, que sua presença sólida e concreta ficou capturada como estava naqueles meses. (Carlos, 2011, p.44).

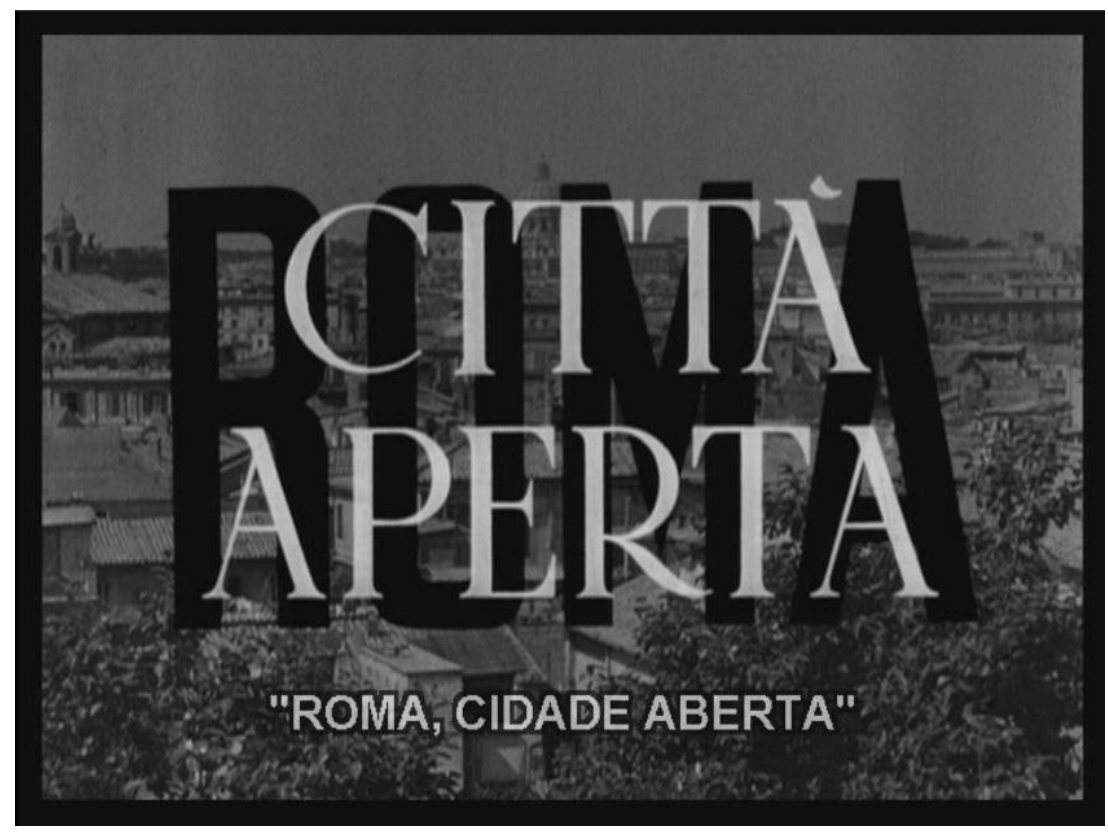

Figura 2: Quadro com título do filme aos 36" durante a cena de abertura de Roma, Cidade Aberta, de Roberto Rosselini (1945).

Nessa primeira cena panorâmica, tem-se a ambientação do filme, a cidade de Roma como espaço geral para as ações que irão acontecer; torna-se importante desde esse momento o aspecto da cidade como um todo para o filme e sua narrativa, como o espaço urbano em sua totalidade, não atrelado a uma ou a outra localidade específica. É exatamente neste ambiente verídico, porém não especificado (um bairro, uma praça, um edifício), que a história se passa, uma história com personagens e fatos fictícios, porém baseados em uma realidade histórica naquela época ainda vigente que, portanto, assistiu a toda a tragédia que possa ser representada durante o filme (ver Figura 3). O caráter de ficção da obra é entendido na medida em que o que ocorre a um personagem poderia ter acontecido a qualquer outro, isto é, o filme não atrela a realidade a um acontecimento pessoal determinado, mas deixa em aberto através de seu realismo a ideia de que seus fatos poderiam pertencer à vida de qualquer 
cidadão que tivesse habitado a Roma que é mostrada nas primeiras cenas desse filme.

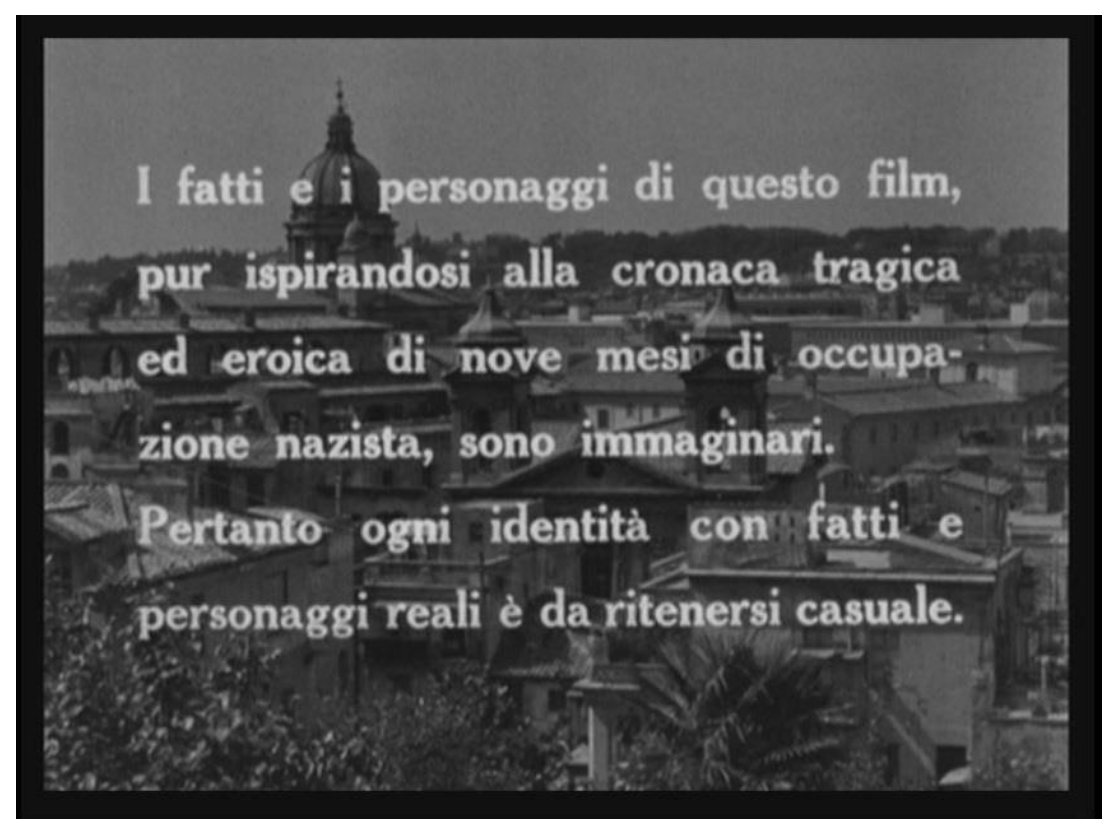

Figura 3: Texto elucidativo sobre a veracidade dos temas abordados, mas atentando para a ficcionalidade dos fatos e personagens, aos 54" de Roma, Cidade Aberta, de Roberto Rosselini (1945).

A obra de De Sica, Ladrões de Bicicleta, também tem como ponto de partida o espaço urbano; no entanto, este é filmado no âmbito local da cidade, e não de sua universalidade, como é feito por Rosselini. Assiste-se à chegada de um ônibus, que é o objeto focado pela câmera em seu percurso, até chegar a um bairro periférico, em que se tem a arquitetura de conjuntos habitacionais da classe operária, denotando desde já a importância desse aspecto para a narrativa do filme. É relevante também observar a representação dessa parcela do espaço urbano como um espaço povoado, em que se vê características da sociedade italiana da época, a parte que (sobre)vive no espaço da cidade do pós-guerra, envolvida em suas ações urbanas e corriqueiras, em meio às dificuldades encontradas. A abertura do filme de De Sica com este aspecto da vida urbana já acusa um importante traço do entendimento do espaço urbano para a narrativa, diferente do encontrado no filme de Rosselini.

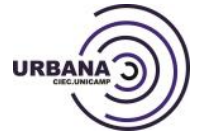


Como visto, Roma, Cidade Aberta começa com uma tomada de paisagens, focando seu aspecto arquitetônico, ao invés de urbano-social, ao contrário do que é visto em Ladrões de Bicicleta, no mesmo trecho. Aliás, essa é uma característica que ambos os filmes carregam por toda sua duração: o primeiro apresenta uma quantidade razoável de cenas externas, que são, no entanto, talvez até menos frequentes que as cenas internas, mostrando a casa italiana, ambientes de trabalho, etc; já o segundo é caracterizado pela presença frequente - a grande maioria - dessas tomadas exteriores, em que o espaço urbano é tido como outro personagem, sempre presente nas ações que são desenvolvidas. Neste último caso, o espaço é sempre povoado, em ações cotidianas típicas da cidade, além da presença de aspectos sociais relevantes do período histórico que o filme se propõe a representar: o espaço urbano da procura de emprego, do transporte público, da arquitetura habitacional de periferia com grandes blocos de edifícios simples e sem ornamentos, os monumentos e arquitetura espetacular (o Estádio, por exemplo)... Entretanto, pode-se dizer que em Roma, Cidade Aberta, são poucas as cenas em que se tem a sensação de urbanidade/civilidade explícita. Duas cenas, no entanto, merecem atenção para uma análise do espaço urbano como aspecto chave no neorrealismo: a cena do "assalto" à padaria (ver Figura 4), com a multidão reunida em frente ao estabelecimento (uso de pessoas locais, não atores); e a cena em que Dom Pietro anda com Marcello rumo à casa de Pina, na qual a rua é mostrada em primeiro plano, e um automóvel passa, seguido por um trólebus que realiza a transição de uma cena para a outra, em que ainda se observa a instabilidade da câmera, quase como numa filmagem amadora, que parece confirmar o cenário real (Figura 5). Nestes dois casos, representa-se o espaço da cidade com seus elementos móveis e estáticos, aliados à presença do homem. 


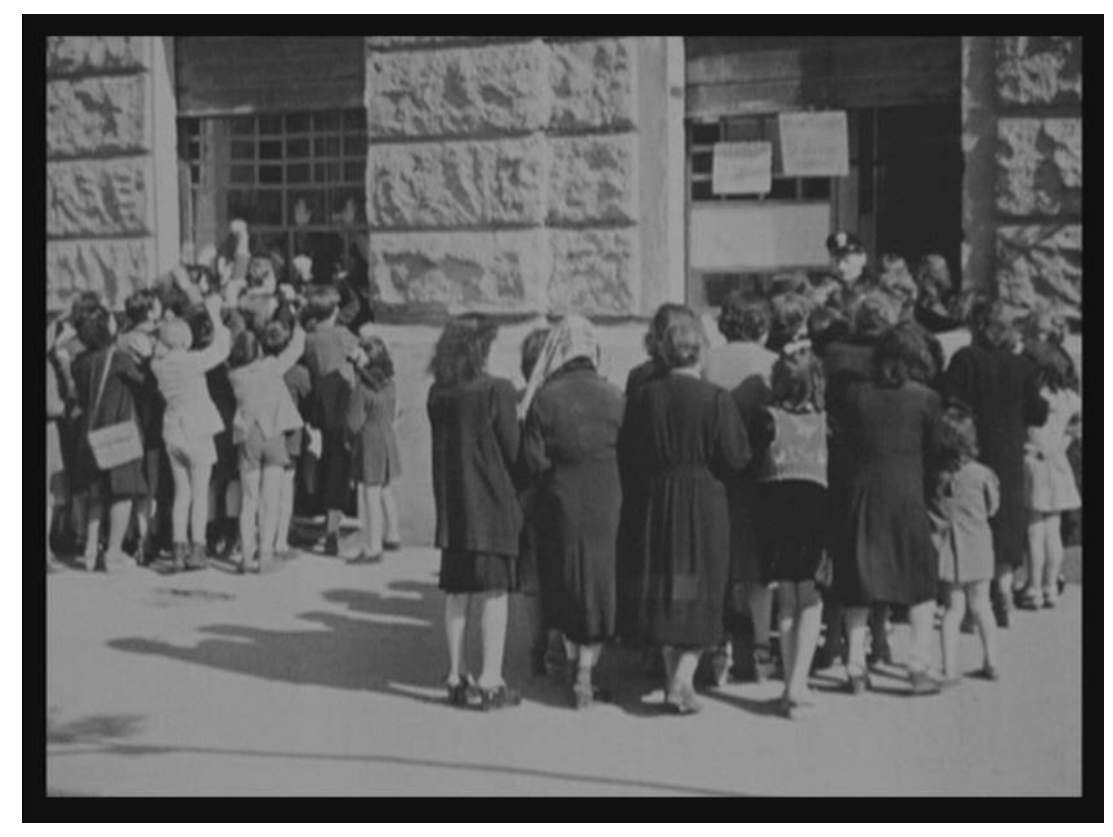

Figura 4: Quadro aos 7'23" de Roma, Cidade Aberta, de Roberto Rosselini (1945). Cena do assalto à padaria. Retrato da miséria e situação de grande parte da sociedade italiana no pós-guerra.

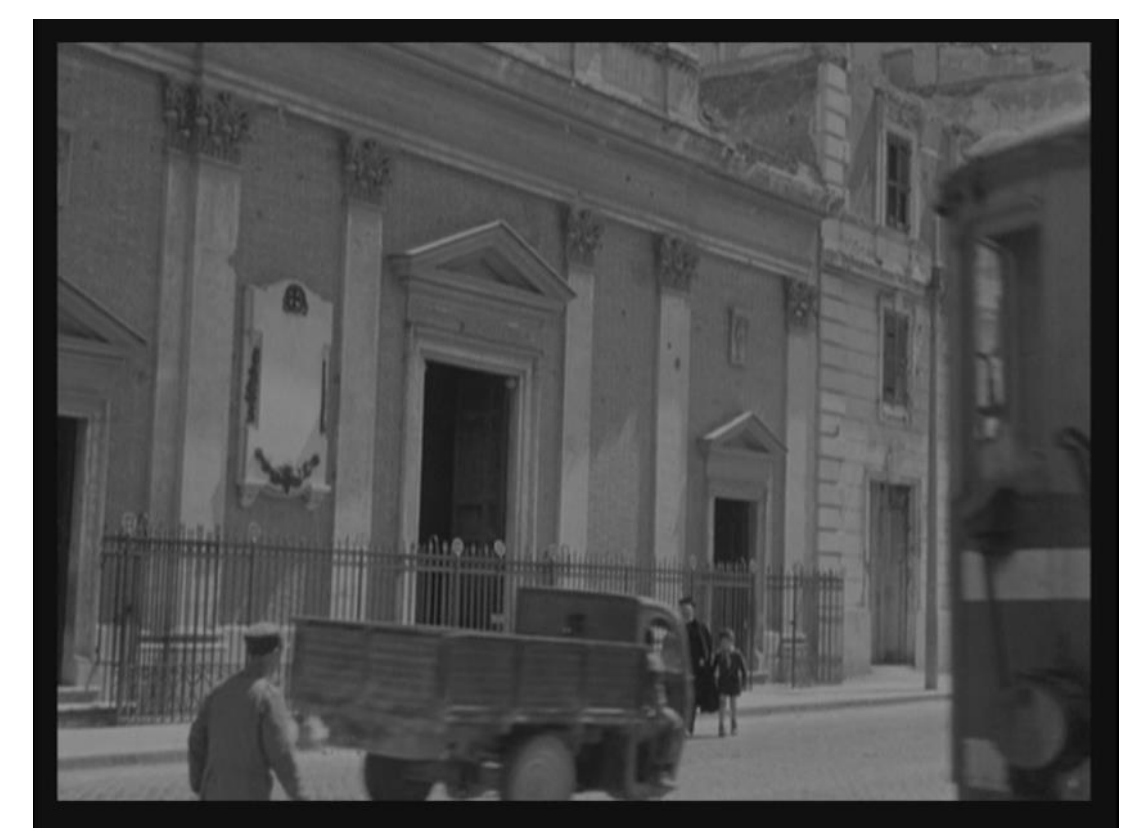

Figura 5: Quadro da cena em que Dom Pietro sai com Marcello em direção à casa de Pina (15'21") em Roma, Cidade Aberta, de Roberto Rosselini (1945). A rua está em primeiro plano, e os personagens encontram-se entre o plano de fundo da arquitetura e o primeiro, com as ações urbanas se desenvolvendo em sua naturalidade e 
autenticidade. A instabilidade da câmera nesta cena também contribui para a sensação de realidade que se pretende transmitir.

Um ponto separador das duas obras está justamente no modo que os diretores apresentam o espaço ao espectador, como base para suas narrativas. Em Roma, Cidade Aberta, os personagens não interagem com o espaço urbano de maneira direta; as paisagens externas são mais um pano de fundo para as ações que de fato palco delas. Grande parte inclusive, em plongée, mostra a cidade ao longe através da visão de janelas de apartamentos. A questão já anteriormente mencionada de que a maioria das situações ocorre em cenários internos parece comprovar a teoria de que o espaço urbano neste filme de Rosselini exerce um papel antes cenográfico. O cenário filmado nas ruas em sua contemporaneidade é mostrado para confirmar a ideia de realidade do filme, e ambientar as ações em locais verídicos, mas, apesar de ser entendido como um personagem da história, tem caráter mais passivo que em Ladrões de Bicicleta, em que o espaço urbano representado exerce uma influência constante sobre as ações dos personagens, que parecem ser guiados por este espaço e suas atividades. De Sica parece focalizar as dificuldades na cidade, encarando as ações talvez como um fato decorrente de um problema extremamente arraigado ao espaço urbano, enquanto Rosselini parece focalizar um problema, que atrelado ao espaço em que é situado, é, na verdade, decorrente, em primeiro lugar, da própria humanidade.

Além do espaço, a noção de tempo que se tem nos dois filmes é crucial para uma análise da sociedade italiana naquele período. A vida em Roma, Cidade Aberta segue o ritmo de inconstância do espaço-tempo pós-guerra. O tempo é rápido, ele não se detém nas emoções humanas, é pautado na atividade. Cena símbolo disso é a talvez mais famosa deste filme, em que Pina é metralhada pelos nazistas, ao correr em direção ao caminhão que leva Francesco, seu amado, junto com muitos outros italianos - o tempo passa na velocidade do acontecimento e dura exatamente o que duraria na realidade. O momento da morte é seguido pela tomada de Marcello, seu filho, correndo aos gritos em sua

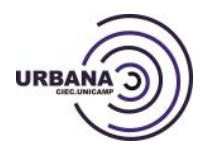


direção e Dom Pietro, que também logo se aproxima, segura-a em seus braços ao som do choro e grito de Marcello, que é retirado à força do local pelo sargento italiano, depois pela cena com um plano único em que Dom Pietro segura o corpo de Pina e o corte para a próxima cena. O tempo fílmico - e aqui se tem a antiespetacularidade - é retratado com a mesma dureza que o espaço pós guerra, não há prolongamentos desnecessários dos acontecimentos, para enaltecer um sentimento ou outro. Assim como na realidade, a carga emotiva de um fato está contida toda em um único instante, e na ação por si só; não se aumenta o impacto ou a sensibilização em relação a um acontecimento pela duração que a câmera o registra. Nesta curta sequência, do momento em que Pina corre, até o momento em que seu corpo é segurado por Dom Pietro, o diretor consegue transmitir todo o sentimento e veracidade que deseja pela fiel reprodução da duração de tal fato na realidade, imortalizado pela tomada pela câmera (ver Figura 6 e Figura 7).

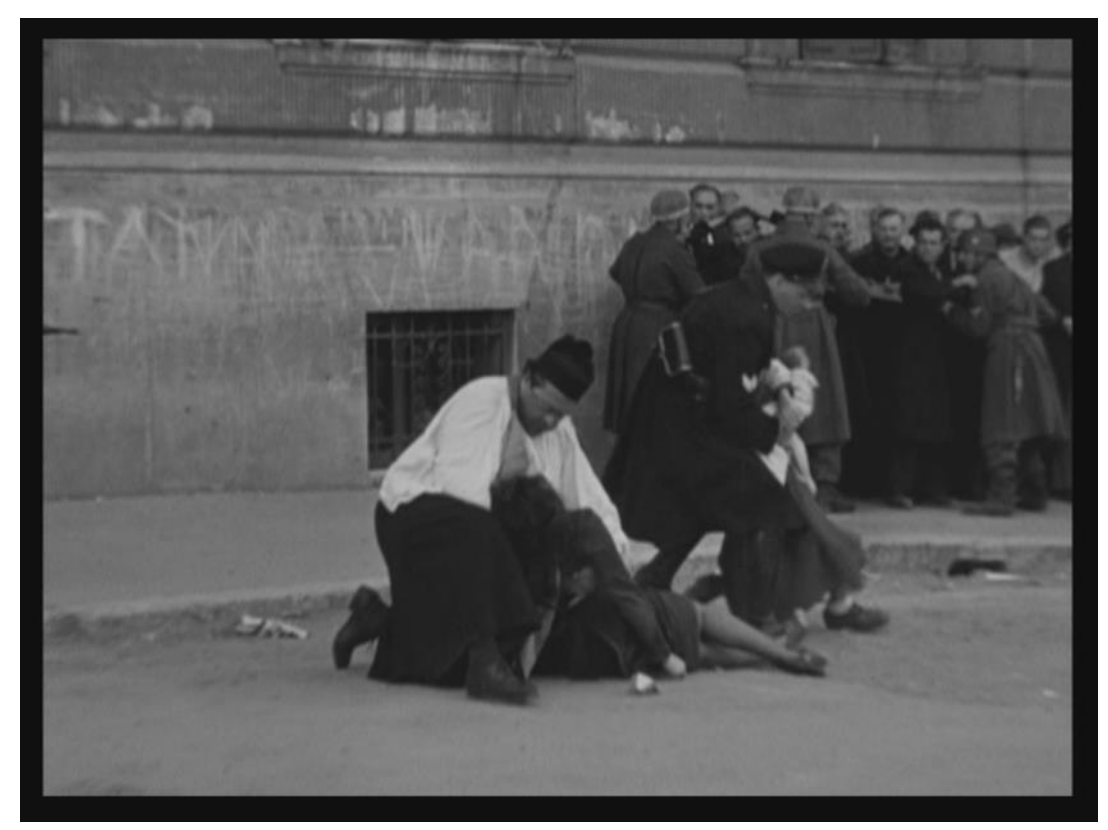

Figura 6: Momento da cena em que Pina é metralhada, quando Dom Pietro a segura em seus braços (56'30"), em Roma, Cidade Aberta, de Roberto Rosselini (1945). O tempo é rápido e brutal, assim como seria na realidade daquele período difícil, em que não há lugar para o drama característico de filmes mainstream em cenas de morte - a realidade seca e rápida como ela de fato é. 


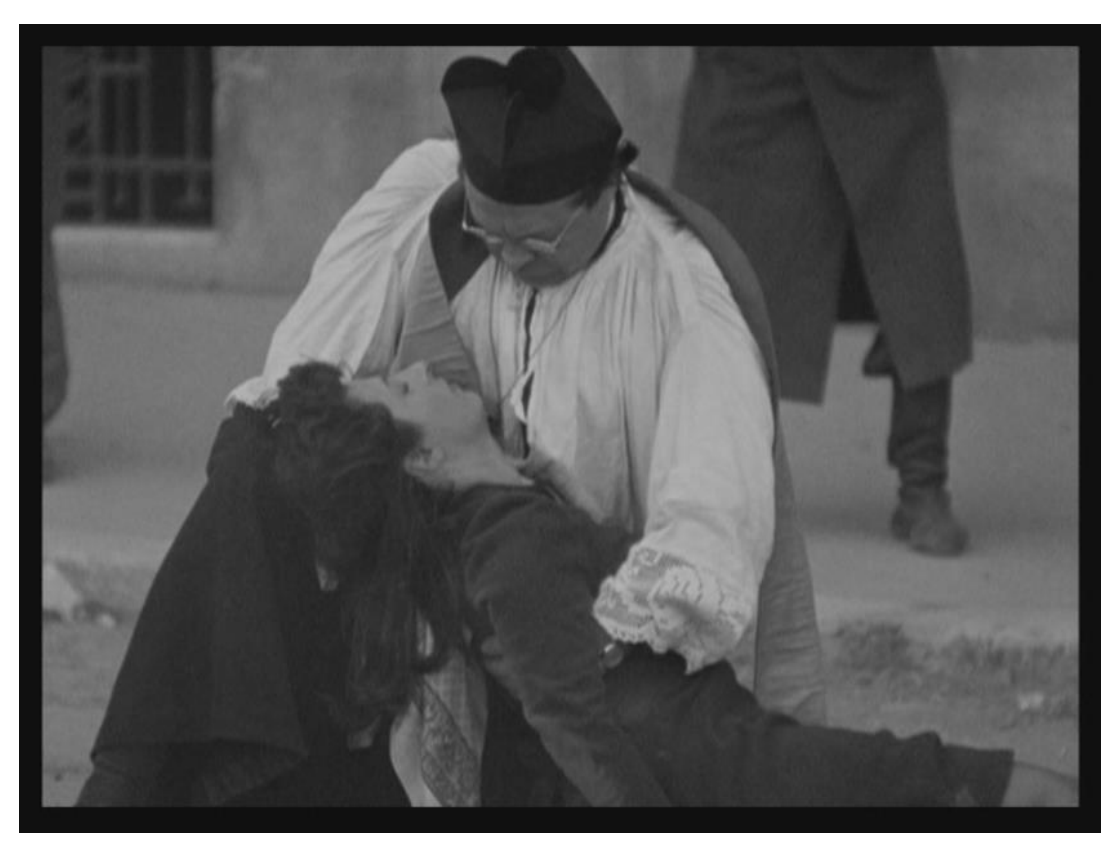

Figura 7: 56'34", Roma, Cidade Aberta, de Roberto Rosselini (1945). Cena master com duração de 4 segundos.

A presença do tempo faz-se notar também no filme de De Sica. Ladrões de Bicicleta é ambientado em sua grande parte, como anteriormente descrito, nas ruas, no fluxo constante da cidade, da dinâmica caótica do espaço urbano. Enquanto Antonio Ricci e seu filho, Bruno, procuram pela bicicleta roubada na metrópole romana, o espaço não para e, o tempo, de igual maneira, também não. Uma cena, entretanto, torna-se relevante para a análise da relação dos personagens com esses elementos: após procurarem sem sucesso por diversas áreas, cansados, com fome e após uma discussão entre Ricci e seu filho, o pai propõe que interrompam a procura e vão a uma pizzaria, uma decisão de "tomarem um tempo" para si próprios e desfrutarem de uma refeição em um bom restaurante, fugindo da difícil situação em que se encontram, ainda que por alguns instantes. Na cena no restaurante, logo que pai e filho adentram o ambiente, a cidade é mostrada pela porta aberta, através da qual ainda é possível ver o fluxo constante de pessoas e automóveis, insistindo que o tempo não parou, quase como um alerta de que aquela atitude dos personagens os custará um tempo inexistente. Há ainda que se observarem as diferentes relações espaço-tempo do ambiente externo e interno: no restaurante, espaço 
$C \mid \in C$

em que predomina a lógica do capital, local de lazer, o tempo transcorre lentamente, um luxo que apenas uma parte da sociedade pode ter (evidenciado na cena inclusive pela população que ali se encontra); já no ambiente externo, predomina a lógica do urbano fragmentado, o tempo veloz que permeia todas as atividades que se desenvolvem nesse tipo de espaço, a concomitância de ações das mais variadas e a coexistência de diversos elementos na paisagem (na cena tem-se carros, transporte público, pedestres e até mesmo um animal parado na porta - ver Figura 8). 

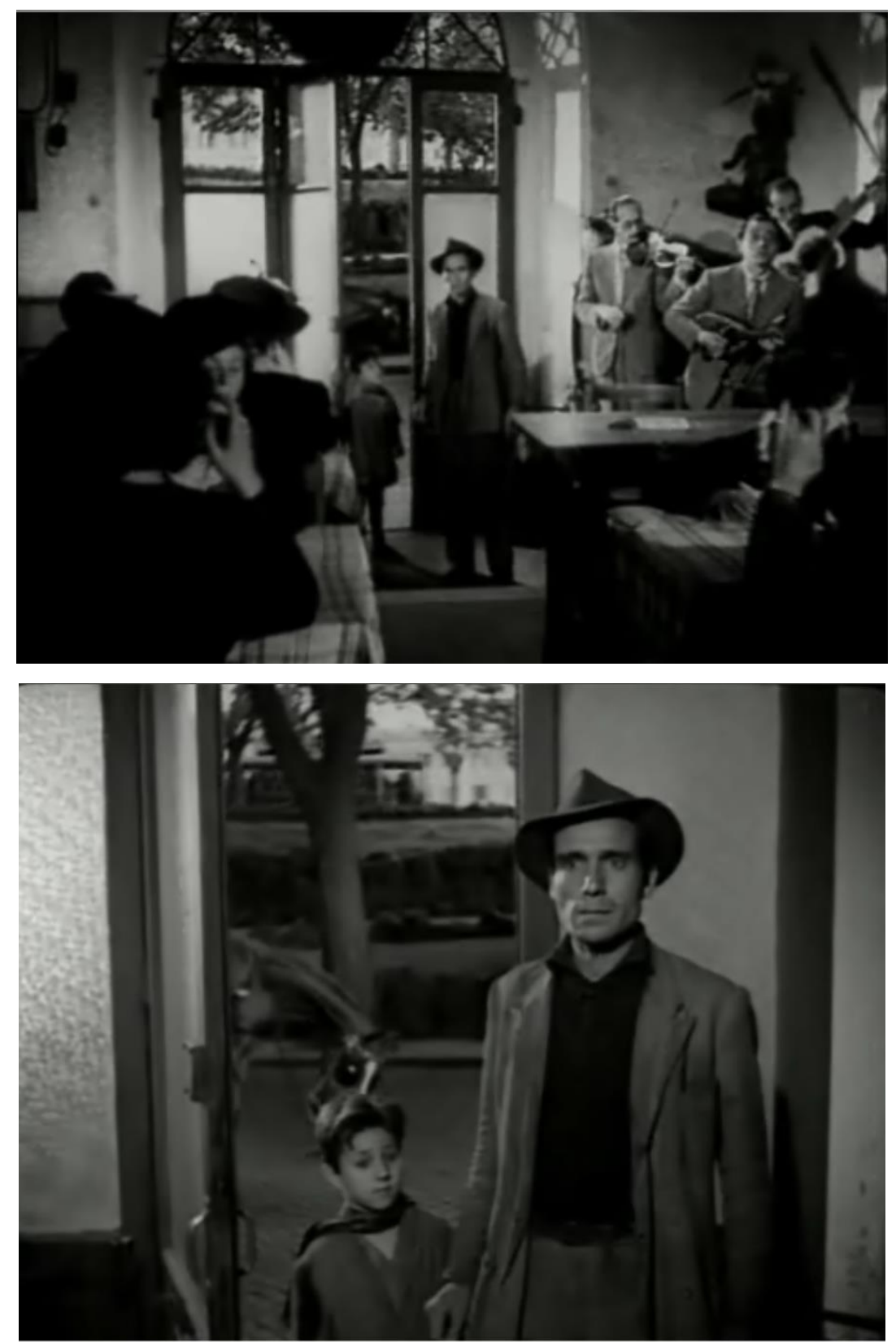

Figura 8: Quadros aos 56'38" e 59'21" de Ladrões de Bicicleta, de De Sica (1948). Cena em que os personagens Antonio Ricci e seu filho Bruno vão ao restaurante. Nestas duas tomadas há a presença do espaço urbano como plano de fundo atrás da porta.

Contraste entre as duas realidades, com duas diferentes relações de espaço e tempo.

Cenografia e Composição Cênica em Roma, Cidade Aberta e Ladrões de Bicicleta

O efeito de autenticidade conferido pelo neorrealismo com as cenas do cotidiano, sejam elas ambientadas nas ruas ou em espaços internos, só é 
possível graças ao trabalho de mise-en-scène pela cenografia e fotografia presente em suas obras. A posição da câmera, a escolha dos objetos, ângulos e iluminação, são apenas alguns dos aspectos que conferem significação à obra, e ao que se deseja transmitir através do aparato fílmico.

Um aspecto interessante de composição de cena observado em Roma, Cidade Aberta é a tomada por um ângulo alto sempre da mostra dos ataques nazistas, em que se tem o ponto de vista a partir de uma janela ou telhado, realçando a posição da Resistência (ver Figura 9). Essa composição como signo de um conceito político e social é ainda mais evidente na cena final do mesmo filme: aqui, as crianças são filmadas de trás, e tem-se a paisagem do skyline romano ao fundo, a mesma imagem que havia sido mostrada no início do filme. Essa visão retratada parece indicar um aspecto psicológico dos personagens envolvidos com tal espaço: a volta à cidade, aos problemas intrínsecos à sua realidade, porém ao mesmo tempo a sensação de um futuro, que se espera carregar uma mudança.

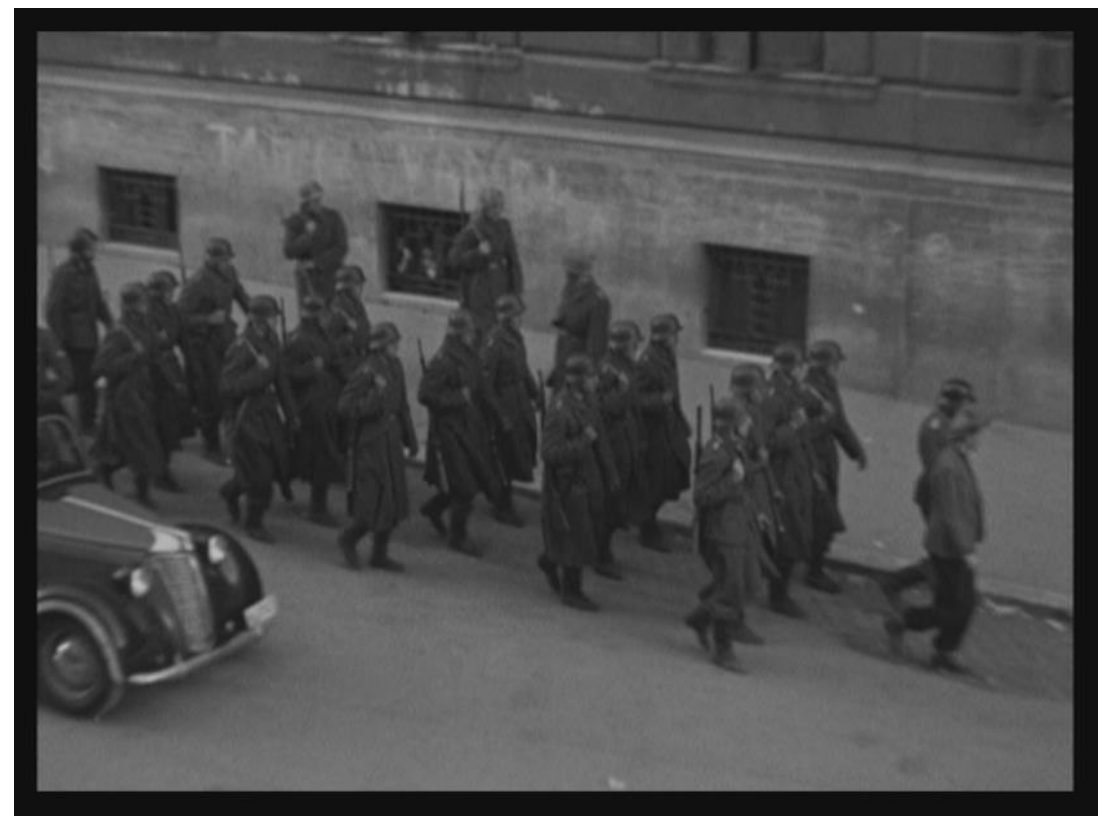

Figura 9: Quadro aos 47'52" de Roma, Cidade Aberta, de Roberto Rosselini (1945). Apenas um dos vários exemplos em que os nazistas, observados do ponto de vista de uma janela, neste caso, a de Pina (ângulo alto) - posição da Resistência.

Outro aspecto relevante na relação dos personagens com o espaço urbano é a profundidade de campo. Ambos os filmes possuem diversas cenas em que a cidade é retratada como plano de fundo: enquanto a ação principal acontece em primeiro plano,

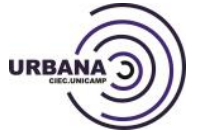
v. 7, n. 10, jan /ago (2015). Dossiê História Urbana: a configuração de um campo conceitual 
tem-se, em segundo, a paisagem da cidade e/ou as ações rotineiras do meio urbano. Esse efeito de profundidade é claro na cena do assalto à padaria, em Roma, Cidade Aberta, nos quadros em que Pina conversa com o sargento italiano em primeiro plano (plano americano), e a cidade se desenvolve ao fundo, com crianças brincando e a vida urbana acontecendo (ver Figura 10). Outro exemplo importante da profundidade de campo que se relaciona, no entanto, mais com a questão do tempo no espaço urbano é notado em Ladrões de Bicicleta, na cena em que os personagens Antonio e seu filho sentam na sarjeta próximo ao Estádio e o pai reflete, inquieto, sobre a sua condição. Nessa tomada, em primeiro plano está a rua, em um plano intermediário os dois personagens sentados e, ao fundo, a calçada, cada qual com ações independentes que compõem aquele espaço (ver Figura 11). Aqui é importante a sensação de velocidade conferida aos passos apressados dos transeuntes ao fundo e das bicicletas rápidas que surgem em primeiro plano, passando da direita para a esquerda. Intensifica-se, com esse recurso na filmagem, a ideia daquela realidade urbana, daquele tempo: um espaço já marcado pela transitoriedade e solidão dos indivíduos da sociedade.

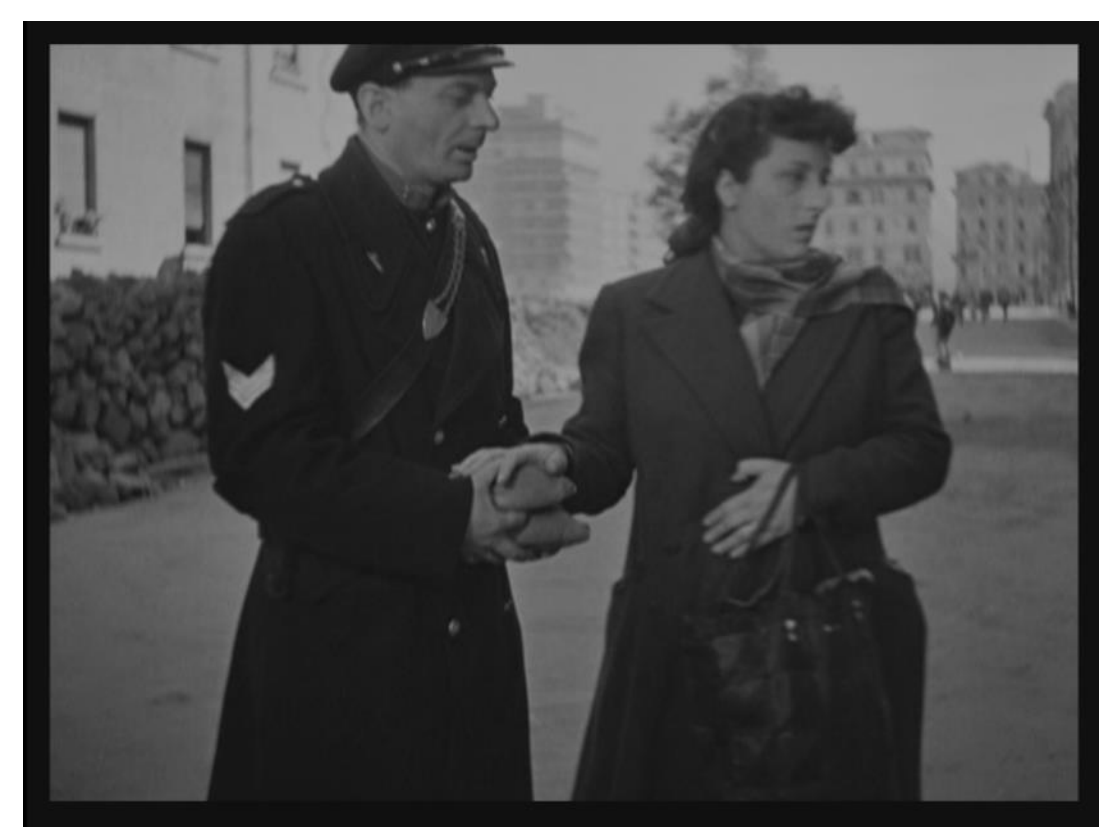

Figura 10: Profundidade de Campo em Roma, Cidade Aberta, de Roberto Rosselini (1945), em quadro aos 8'38". A ação principal ocorre em primeiro plano, com os personagens mostrados em plano americano, mas em segundo plano tem-se o desenrolar de atividades corriqueiras do meio urbano: transeuntes, crianças brincando.

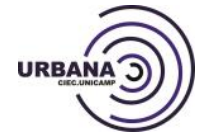
v. 7, n. 10, jan /ago (2015). Dossiê História Urbana: a configuração de um campo conceitual 
A presença da arquitetura como formadora deste espaço também é de extrema relevância para a mise-en-scène.

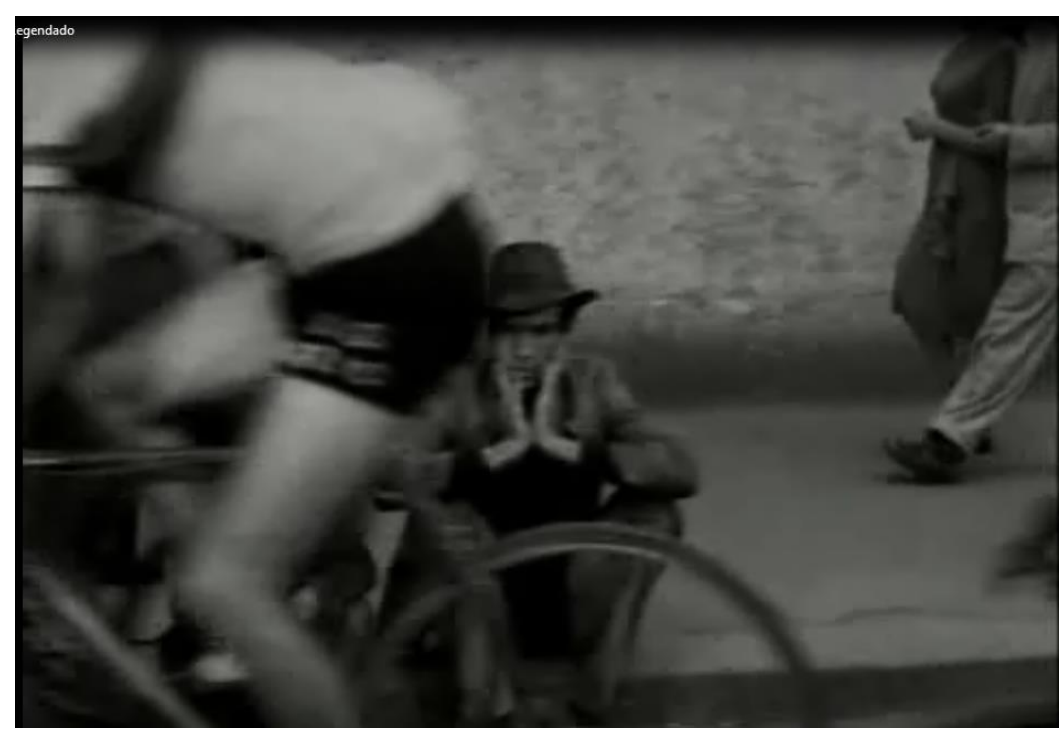

Figura 11: 1h22'19" de Ladrões de Bicicleta, de De Sica (1948): Profundidade de campo desta cena representa a questão do tempo na sociedade moderna: a velocidade impera, e o homem é apenas mais um indivíduo sozinho e estranho situado numa sucessão de eventos comandados pelo tempo que devora, e não mais pela continuidade de espaços.

Em Ladrões de Bicicleta, cabe atentar para a cena final. Ricci e seu filho, após a longa jornada à procura de sua bicicleta, uma jornada que inclusive é mostrada em um tempo compatível com a duração temporal na realidade, encaminham-se, frustrados e sem esperança, em meio à multidão que povoa o espaço urbano em um movimento contínuo, ininterrupto. Começando com uma câmera frontal que registra a emoção daqueles personagens, intercalando ângulos baixos e médios para mostrar a expressão de Bruno e de Antonio, em que se exprime claramente a falta de perspectiva, o drama da luta pela sobrevivência, passa-se para uma tomada com a câmera filmando-os de costas, num ângulo mais alto, com a câmera fixa, que acompanha o movimento de distanciamento dos dois, que, seguindo em frente, perdem-se em meio àquela massa, numa alegoria da cidade que os suga, os consome, uma sociedade que tenta sobreviver às difíceis condições de seu tempo, que acometem muitos 
$\mathrm{Cl} \in \mathrm{C}$

daqueles cidadãos italianos, apesar da relação de indiferença e estranhamento existente entre eles no espaço urbano partilhado (ver Figura 12).

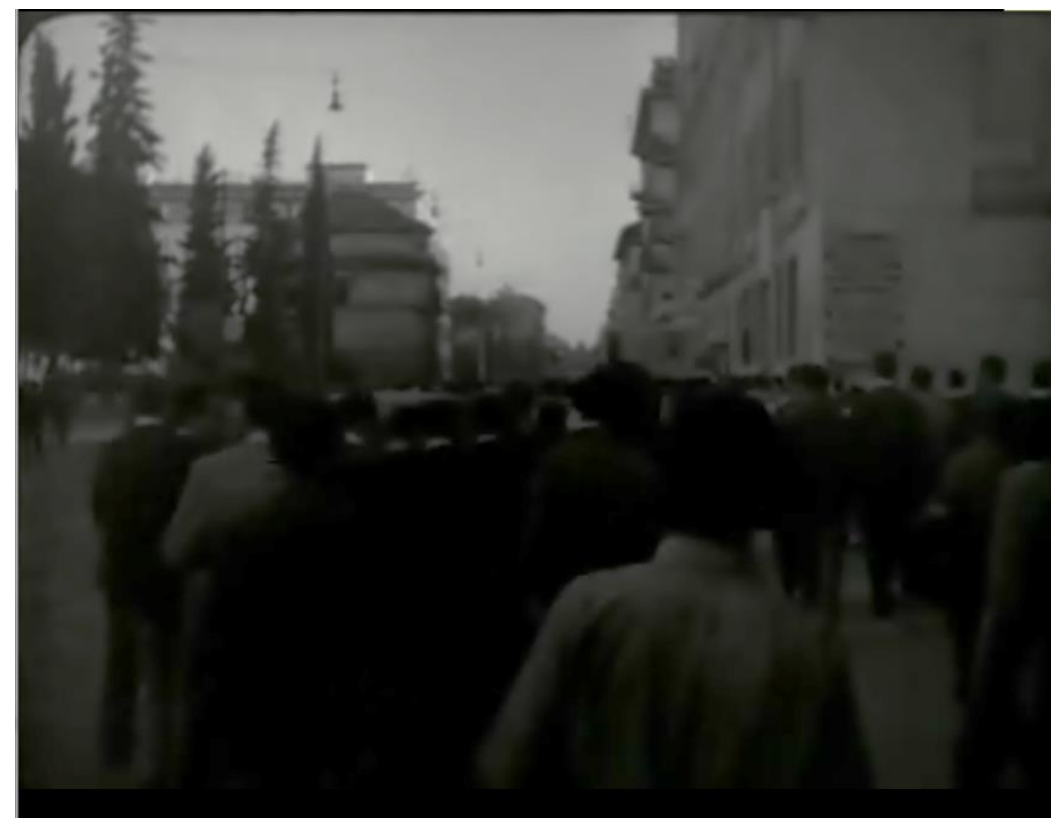

Figura 12: Quadro aos 1h27'35" de Ladrões de Bicicleta, de De Sica (1948). Cena final.

Nessa tomada, os personagens Antonio e seu filho caminham para longe da câmera, em meio à multidão no espaço urbano.

\section{Luz/Sombras}

A luz é sem dúvida um dos aspectos mais importantes na mise-en-scène, não só em ambientes internos com a necessidade de aparato luminotécnico, mas também em ambientes externos, com a luz natural. O neorrealismo, com cenas em sua maioria filmadas fora de estúdios, utiliza-se muito da iluminação natural, que ora contribui para a sensação de familiaridade com a ambientação real e autenticidade, ora produz efeitos específicos que se relacionam com a ação dos personagens de maneira a produzir um significado.

No primeiro caso, da luz utilizada como sustentação do efeito de realidade que se deseja imprimir ao filme, tem-se a cena da marcha dos soldados alemães, logo no início de Roma, Cidade Aberta, em que, enfileirados, seguem cantando uma canção patriótica em alemão, passando pelas ruas desertas de Roma durante a noite (ver Figura 13). O ponto de vista inicial para essa cena é uma rua entre dois edifícios, como se quem filmasse estivesse escondido (o que de

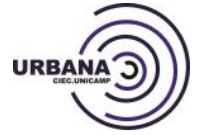


fato poderia ser, já que Rosselini de fato filmou muitas cenas reais na cidade, fugindo dos alemães durante o período de ocupação, e posteriormente colocou alguns desses recortes em seus filmes). O enquadramento inicial desta cena favorece a visão da arquitetura como plano de fundo - uma igreja, que é revelada por essa moldura, exaltando também aí a importância do edifício para a identificação do espectador com o espaço filmado, para a sua identificação com a cidade de Roma e, portanto, com a realidade. Além disso, a não utilização de um aparato luminotécnico para a cena indica a autenticidade do momento registrado ou, ao menos, contribui para tal efeito, crucial para a estética neorrealista.

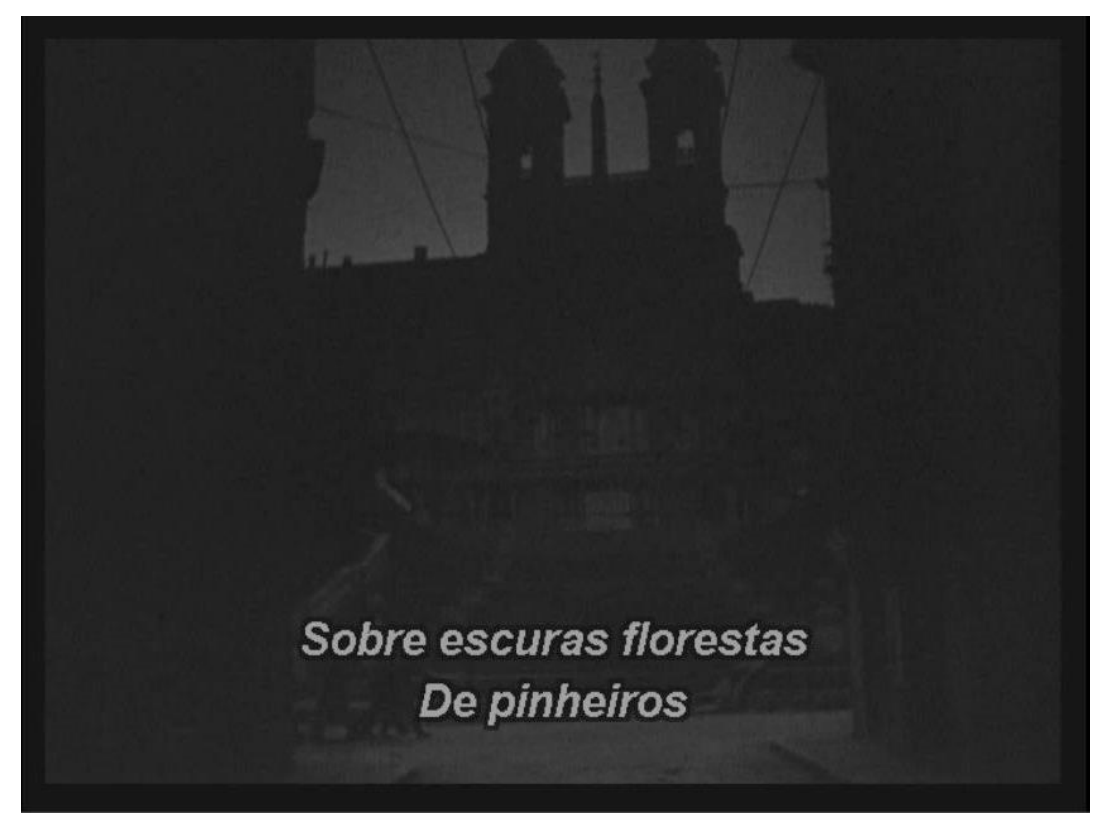

Figura 13: Quadro ao 1'12"de Roma, Cidade Aberta, de Roberto Rosselini (1945). Cena em que soldados alemães cantam uma canção patriótica em sua língua enquanto marcham pelas ruas de Roma, no período noturno. A importância da luz como representação fiel da realidade.

O uso da luz provoca muitas vezes efeitos de contraste, entre claro e escuro, por exemplo, gerando significados próprios à imagem. No início de Ladrões de Bicicleta, tem-se um bom exemplo disso, quando Antônio Ricci diz "Me Sinto como um homem acorrentado", e as sombras na parede parecem colocá-lo atrás de uma "grade" (ver Figura 14). Outro exemplo do mesmo filme,

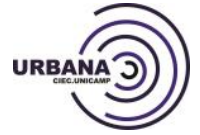



com a luz exercendo papel chave na impressão de significado, é o contraponto entre o momento de exaltação quando Ricci pega sua bicicleta e vai ao trabalho pela primeira vez, passando por uma grande praça em que se tem ao fundo um edifício ao longe iluminado pelo sol, um Arco, relembrando um Arco do Triunfo (ver Figura 15), e o momento em que, após ter tido sua bicicleta roubada, volta para casa com o filho, Bruno, após busca-lo no posto de gasolina: filmados de costas, a sombra os torna completamente pretos, numa composição que parece comprovar a falta de perspectiva que assola aquele cidadão e sua família (ver Figura 16).

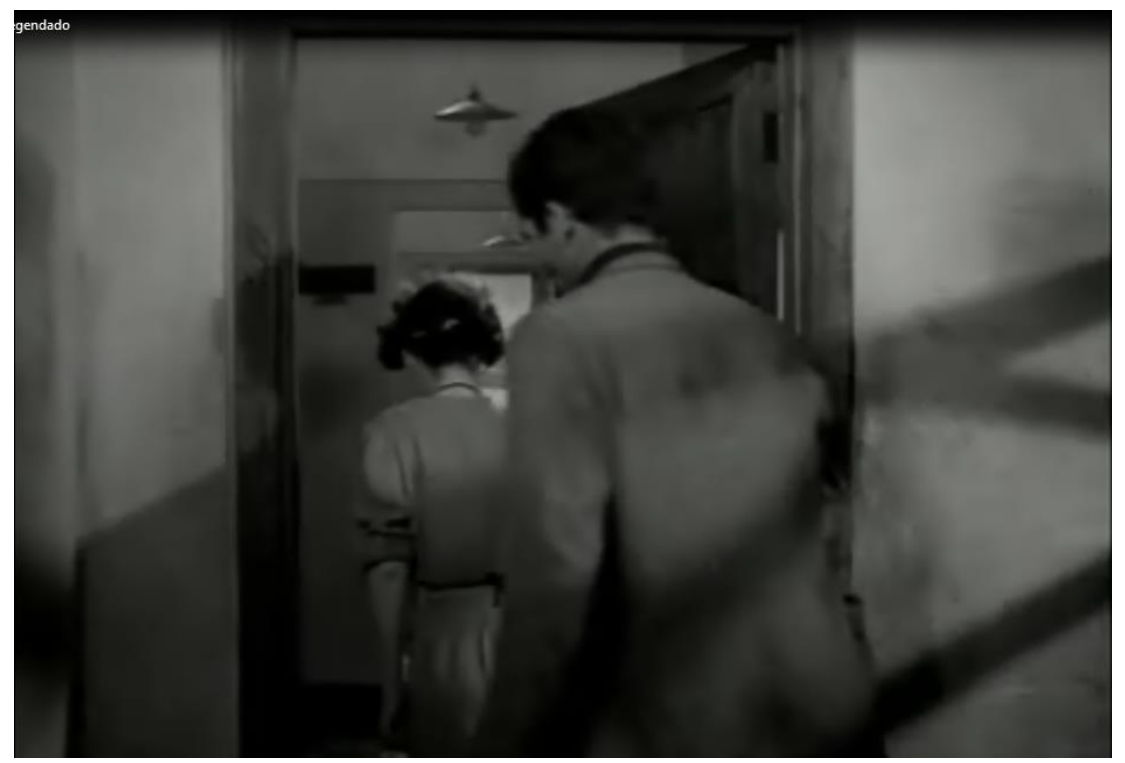

Figura 14: Quadro aos 4'56" de Ladrões de Bicicleta, de De Sica (1948). O efeito da sombra sobre o corpo do personagem principal, Antônio Ricci. 


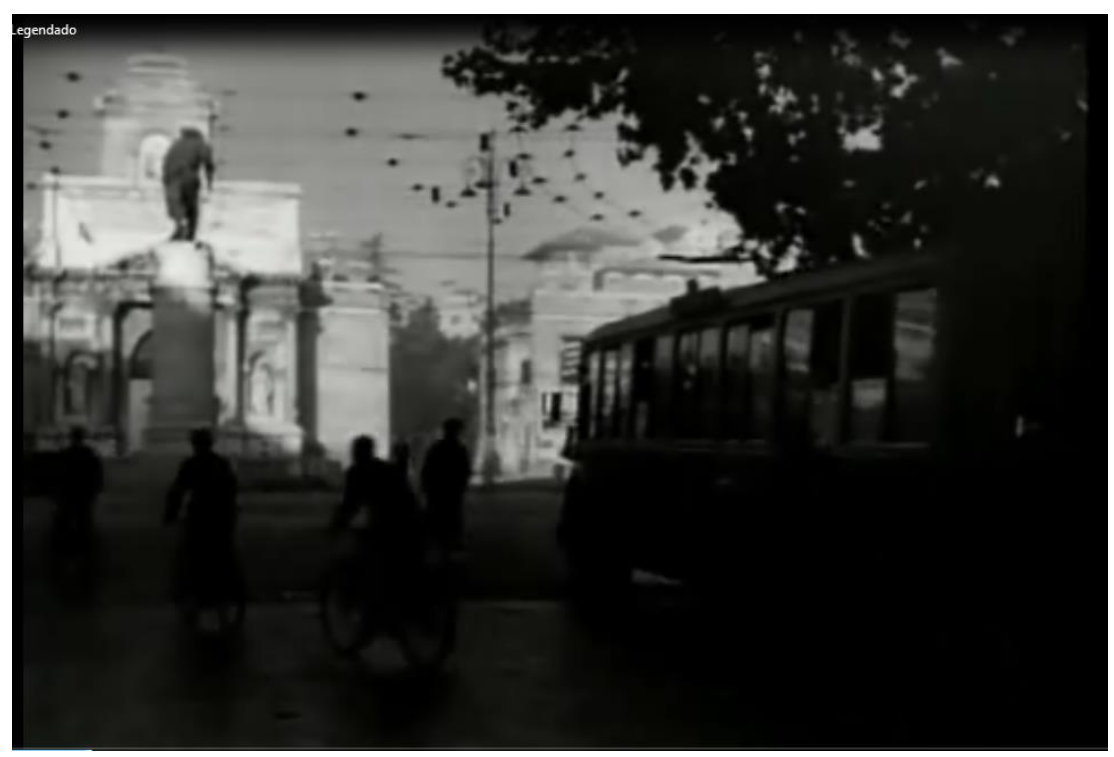

Figura 15: 17'14" de Ladrões de Bicicleta, de De Sica (1948). Luz exalta a arquitetura ao fundo, em que se tem um arco, como os arcos do triunfo. Possível relação com o estado de espírito do personagem.

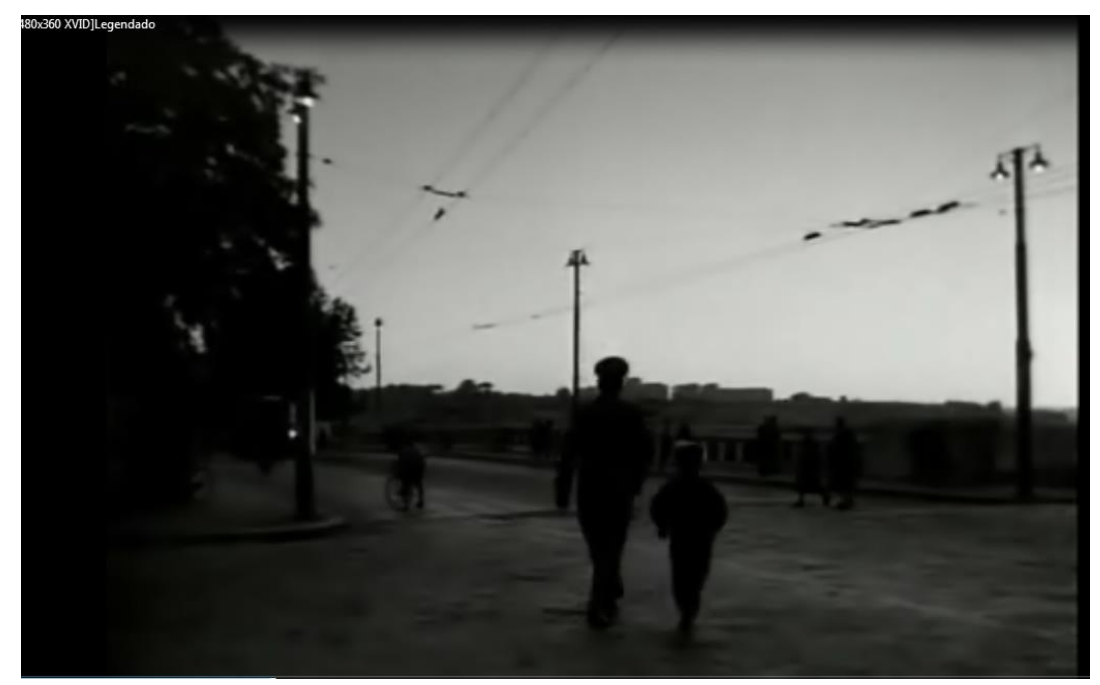

Figura 16: 24'26" de Ladrões de Bicicleta, de De Sica (1948).

Ainda no filme de De Sica, outro momento que se pode ressaltar é no final do filme, quando, já exaurido de qualquer esperança, após procurar o dia todo sem sucesso com seu filho por sua bicicleta, Ricci fica em dúvida se rouba a bicicleta encostada na parede de um edifício próximo ao estádio: neste momento, a sombra no chão parece dividir o enquadramento cênico com uma linha diagonal (ver Figura 17), separando claro e escuro, numa analogia ao certo e errado, e, coincidentemente ou não, ele se encontra no lado da sombra. Ricci 
observa de longe a bicicleta, em uma espécie de conflito interno do personagem, em cenas que intercalam o espaço urbano povoado em sua transitoriedade e velocidade, com a sugestão de um possível "anonimato" e talvez chance de sucesso para o furto, e imagens de uma rua pacata onde a bicicleta repousa, totalmente iluminada pela luz solar, podendo significar um caminho de esperança para o personagem. Aí é possível estabelecer uma relação do espaço povoado com a ação do personagem: a ideia de que a sociedade se transforma, aos poucos, desde o início da modernidade, em um aglomerado de estranhos sem relações entre si, permitiria que uma ação condenada, como um furto, passasse despercebida pelos tantos olhos que circulam pelas cidades, numa situação de indiferença por parte dos transeuntes que é intensificada por esse espaço dos passos rápidos e solitários. Esse aspecto da vida em sociedade nos centros urbanos foi tema corrente para filósofos, literários e sociólogos desde o final do século XIX, como Charles Baudelaire, Georg Simmel (destaca-se o texto "A metrópole e a Vida Mental", de 1902). A partir desse ponto, poder-se-ia sugerir até mesmo que teria sido mais fácil o furto em meio a todas as pessoas pegando suas bicicletas no bicicletário, que a escolha de uma única em um espaço em que a fluidez e dinâmica do urbano se mostrava bastante diferente daquela próxima ao centro de grande fluxo de pessoas, próxima ao estádio (ver Figura 18 e Figura 19). 


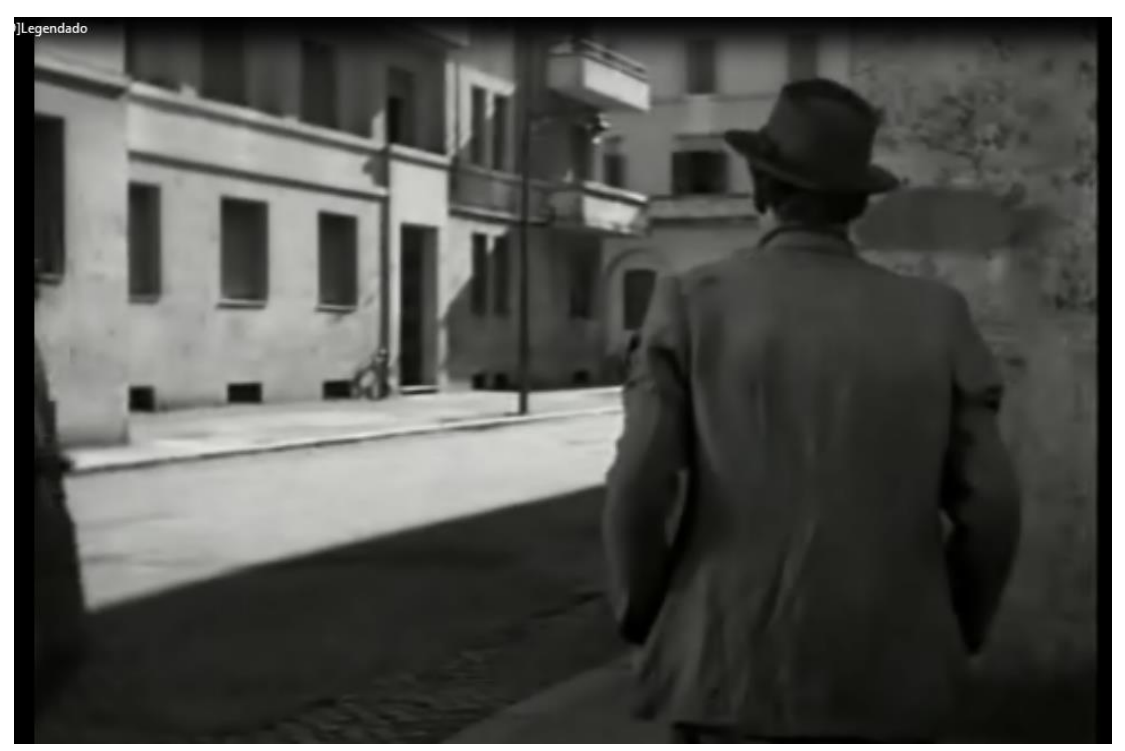

Figura 17: Quadro à 1h 22'54" de Ladrões de Bicicleta, de De Sica (1948). A "divisão" provocada pelo efeito de claro/escuro com a parte iluminada da cena e a parte em sombra, como significação de uma decisão moral a ser cumprida pelo personagem. 0 personagem Ricci observa a bicicleta encostada no muro do edifício, do outro lado da rua.

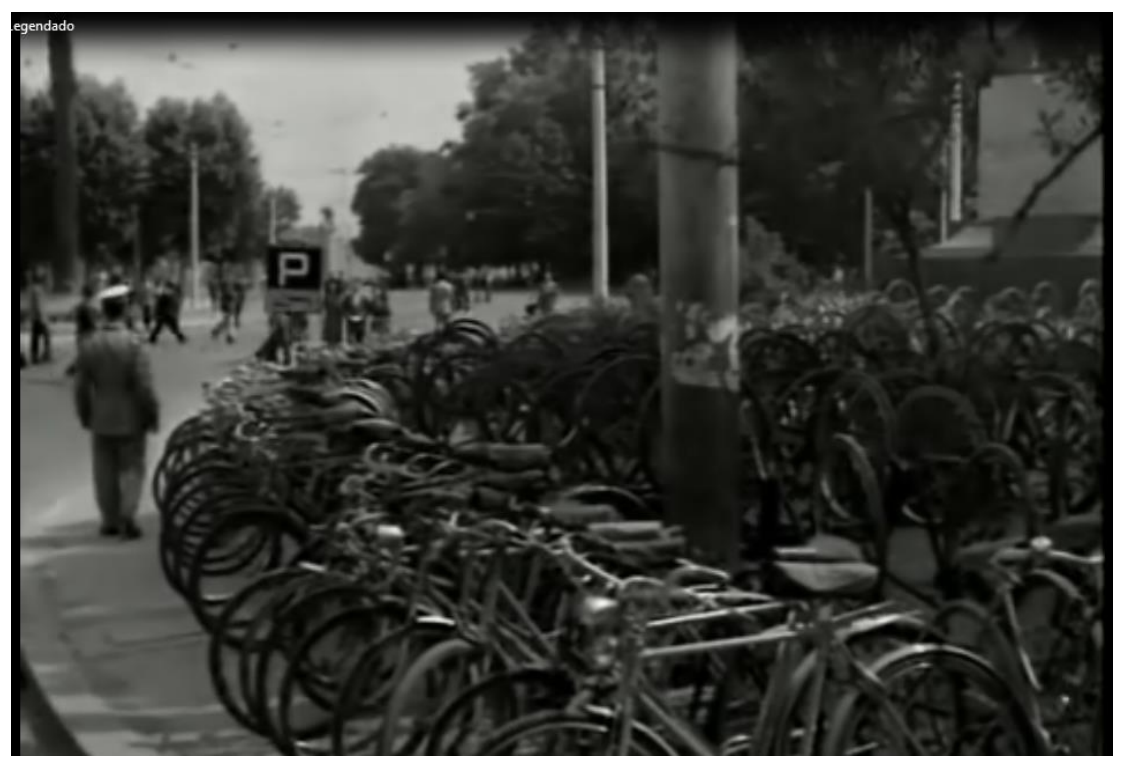

Figura 18: 1h21'20" em Ladrões de Bicicleta, de De Sica (1948). O contraponto espacial das bicicletas que o personagem Ricci observa: enquanto uma situa-se em uma rua calma, encostada no muro de um edifício, aqui se tem um aglomerado de bicicletas, assim como inúmeros passantes ao fundo, retratando a dinâmica dos lugares movimentados de uma cidade. 


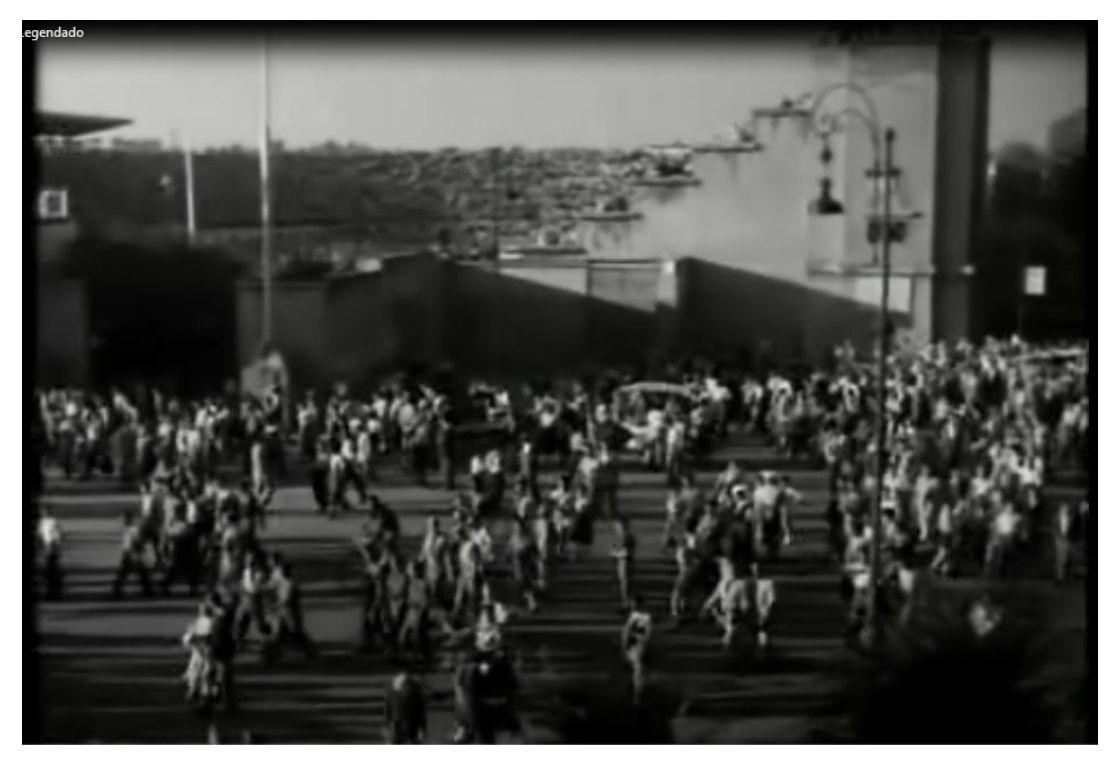

Figura 19: 1h22'37" de Ladrões de Bicicleta, de De Sica (1948). O espaço do anonimato e das relações de impessoalidade. Aqui o público que estava no estádio vai embora, alguns em direção ao bicicletário.

\section{A Noção de Comunidade}

Em meio ao ambiente hostil da cidade pós-guerra retratado por Rosselini e De Sica, ainda é possível observar em alguns momentos traços de um sentimento de coletividade arraigado aos cidadãos, que é visto como uma resistência à tendência de individualização constante da modernidade. Para Zygmunt Bauman, "Em termos sociológicos, o comunitarismo é uma reação esperável à acelerada "liquefação" da vida moderna, (...)" (Bauman, 2000, p.195) O indivíduo "livre", cada qual estranho em relação ao outro, em meio à "nova" sociedade urbana, tem ainda uma história comum, coletiva, que o une aos demais, mas que se enfraquece cada vez mais com o passar do tempo. Em contrapartida, o desejo de ser parte de um grupo e a existência dos mesmos aparecem como uma espécie de fuga ao sentimento de exclusão arraigado à nova urbanidade, que parece conferir aos homens de uma sociedade o caráter de passantes, e não de membros. Na Itália da década de 1940 o processo não estava nem próximo do nível de estranhamento atingido pelas pessoas no final do século $X X$, início do século XXI, mas, como parte de um processo e importante

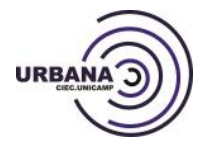

REVISTA ELETRONICA DO CENTRO INTERDISCIPLINAR DE ESTUDOS SOBRE A CIDADE . ISSN 1982-0569 v. 7, n. 10, jan /ago (2015). Dossiê História Urbana: a configuração de um campo conceitual 
período histórico, é relevante atentar para as relações entre os indivíduos que são percebidas ao longo dos dois filmes em questão.

Primeiramente, pode-se mencionar, em Roma, Cidade Aberta, a questão do comportamento de Marina, a amante de Manfredi, cuja traição custa a vida de seu companheiro, em meio a subornos e ilusões: dominada por uma lógica do consumo, aliada à falta de ética, características que se intensificam no período pós-industrial, é símbolo da fragilidade dos laços humanos, um aspecto colocado por Bauman como característica da modernidade líquida. Segundo o autor:

O suprimento de provisões se esvai rapidamente, enquanto o volume de responsabilidades individuais (atribuídas, quando não exercidas na prática) cresce numa escala sem precedentes para as gerações do pós-guerra. Um aspecto muito visível do desaparecimento das velhas garantias é a nova fragilidade dos laços humanos. A fragilidade e transitoriedade dos laços pode ser um preço inevitável do direito de os indivíduos perseguirem seus objetivos individuais, mas não pode deixar de ser, simultaneamente, um obstáculo dos mais formidáveis para perseguir eficazmente esses objetivos - e para a coragem necessária para persegui-los. (Bauman, 2000, p.195)

Em segundo lugar, tem-se a comparação de duas situações distintas em Ladrões de Bicicleta, em relação ao furto da bicicleta de Ricci. No primeiro furto, Ricci está pendurando cartazes e, apesar de haver inúmeros passantes naquele local totalmente urbano, não há uma relação íntima entre a rua e as pessoas. Já no segundo furto, quando Ricci decide roubar a bicicleta, também encostada na parede - assim como a sua estivera -, apesar de não haver quase ninguém na rua, o homem sofre as consequências do espaço arquitetônico daquelas ruas estreitas de caráter bairrista: os olhos que tudo veem a partir daquelas janelas (em uma referência à crítica de Jane Jacobs durante a década de 1960 em sua

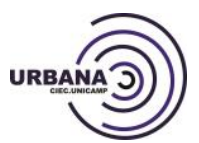


obra Morte e Vida das Grandes Cidades), de prédios de poucos andares, onde os vizinhos ainda se conhecem, percebem logo o furto e com um sentimento de coletividade, identificação e pertencimento àquele determinado lugar/grupo, ajudam o dono verdadeiro do objeto a recuperá-lo do novo ladrão. Esse senso de vida em comunidade é também percebido no prédio onde Ricci vai procurar o suposto ladrão de sua bicicleta. O que se vê nesta cena é a clara demonstração de um espírito coletivo de ajuda mútua, proteção, um universo paralelo ao encontrado diariamente na transitoriedade dos espaços fluidos na dinâmica urbana da velocidade: Ricci é alertado a nunca mais aparecer na Via Pânico, pois ao ter se desentendido com um dos moradores daquele "pedaço", envolveu-se em uma briga coletiva com todos os outros (e aqui cabe o sentido para essa palavra por José Roberto Magnani e também elucidado no texto de Roberto da Matta, A Casa e a Rua, que trata das relações do privado e do público/semipúblico, do sentido de coletividade e pertencimento a uma ou outra esfera). Isso deve-se às relações sociais de proximidade e comunidade que a arquitetura e o espaço construído são capazes de estabelecer. Essas relações traçam fronteiras simbólicas de pertencimento, indicando quem está "dentro" e quem está "fora" (Leal, 2007).

O termo (o "pedaço") na realidade designa aquele espaço intermediário entre o privado (a casa) e o público, onde se desenvolve uma sociabilidade básica, mais ampla que a fundada nos laços familiares, porém mais densa, significativa e estável que as relações formais e individualizadas impostas pela sociedade (Magnani, 1984, p.138 apud Leal, 2007).

Em Roma, Cidade Aberta, percebe-se também esse senso de coletividade muito arraigado nos moradores do edifício de Pina; eles protegem-se, defendem-se, ajudam-se - cobrem a fuga de Francesco e de outros homens contra os soldados nazistas, consolam-se - como na cena em que as mulheres estão aglomeradas no pátio interno do edifício e uma chega aos prantos, após

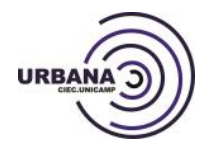


ter seu filho levado pelos nazistas, sendo logo acolhida pelas demais (ver Figura 20). No espaço da cidade, no ritmo frenético das ações e relacionamentos, o homem está sozinho, é apenas mais um na multidão.

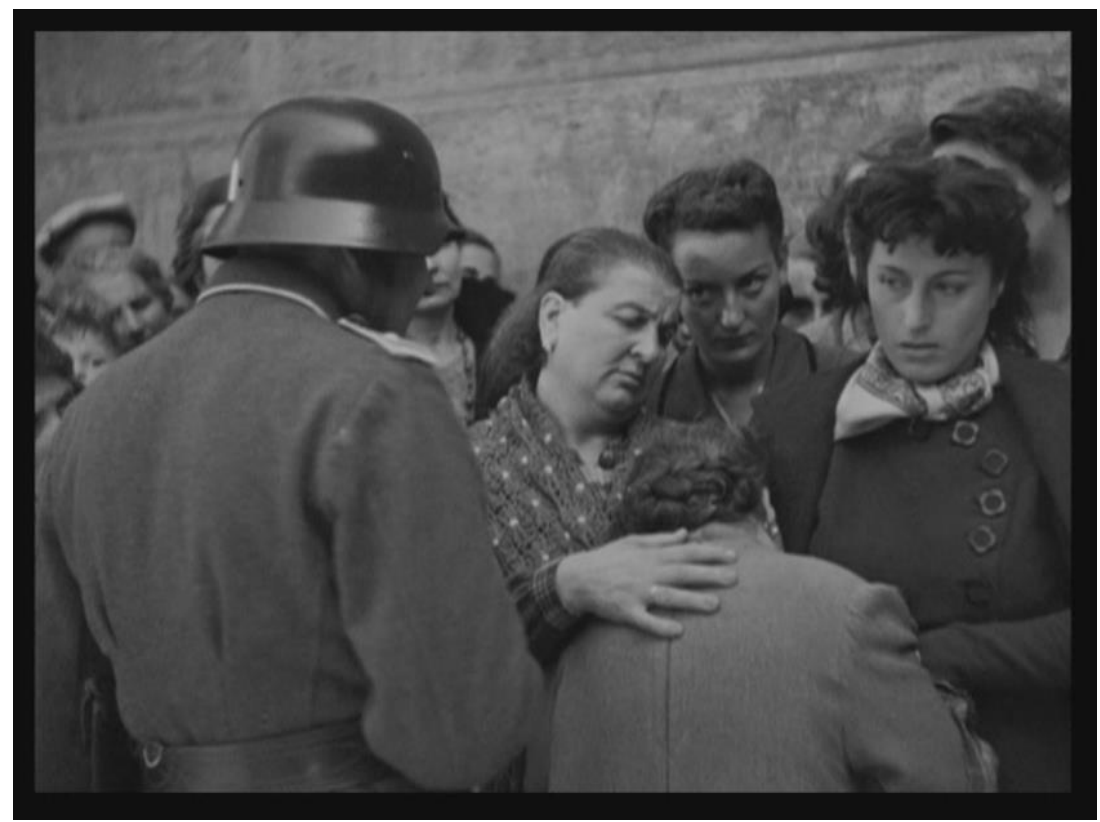

Figura 20: Quadro aos 55'30" de Roma, Cidade Aberta, de Roberto Rosselini (1945). As mulheres, aglomeradas ao longo do muro, prestam assistência a uma vizinha, que acaba de ter seu filho levado pelos oficiais nazistas. Sentimento de auto-ajuda e comiseração.

\section{Conclusão: O Neorrealismo como uma nova visão de mundo}

Apesar do declínio do neorrealismo cinematográfico já em meados da década de 1950, não se pode negar o valor da produção desse período de quase dez anos, em que se pensou o mundo de forma a quebrar pré-conceitos existentes e revelar uma realidade social decorrente da observação crítica e dos impulsos pessoais de cada artista que, no entanto, partilhavam a mesma atualidade. O neorrealismo é precursor para uma série de movimentos deflagrados na década de 1960, dentre eles a Nouvelle Vague francesa e o Cinema Novo (alemão e brasileiro). Sua estética foi, se não parte de um movimento, parte de um estado de espírito de uma parcela da sociedade que não se satisfazia mais com os parâmetros saturados produzidos e repetidos até 
então. Um desejo de resistir frente a uma realidade dura e brutal do pós-guerra, que exigia novas maneiras de relação com a arte.

Mais do que uma escola ou uma técnica cinematográfica, inicialmente, o neo-realismo foi um ato de otimismo coletivo e revolucionário; tanto isso é verdade que não atingia somente o mundo do cinema, mas quase toda a cultura italiana do apósguerra. Foi, em resumo, antes um impulso humano e moral do que uma orientação estética; mas era, também, o modo mais direto que se oferecia aos intelectuais para participarem, após tantos anos de ausência, da vida pública e política da nação. A redescoberta da Itália como pátria comum, de uma Itália que nascia sob o signo da liberdade, foi o ponto de partida do neorealismo. (CAPRI, 1958, p. 23 in: FABRIS, 1996, p.120)

É nesse contexto que se situa o Novo Realismo nas artes plásticas, surgido na França durante a década de 1960, com o intuito de reaproximar a arte de questões sociais, e reforçar seu poder emancipatório, em contraposição a movimentos anteriores que haviam se tornado estilos institucionalizados, como grande parte da produção de arte abstrata. Tem-se como um de seus expoentes a figura de Jean Tinguely, um escultor suíço com obras que se estendem desde a década de 50 até a década de 90 . Em suas obras, o artista propõe o uso de restos industriais, "despojos do progresso" como arte, em instalações que demandam uma posição ativa do espectador, que deve não só contemplar a obra, mas interagir com a mesma, através de um comportamento crítico diferente do convencional (ver Figura 21). Em suas obras, os materiais utilizados não são camuflados, são expostos em seus aspectos originais, reais. Dessa forma, em uma analogia entre Neorrealismo cinematográfico e Novo Realismo das artes plásticas, tem-se como um dos principais fatores a mudança no posicionamento do espectador em relação à obra de arte: este deve assumir um papel ativo; tanto no primeiro, quanto no segundo, é convidado a participar do

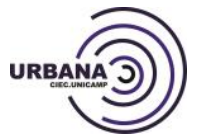


que se é mostrado. No primeiro, o espectador na década de 1940 sente-se parte daquela realidade pós-guerra retratada nas telas, e é convidado a uma reflexão, ao contrário do que o cinema de entretenimento e lazer mainstream se propõe a fazer; no segundo, o espectador transpassa a barreira do distanciamento com a obra de arte e é incitado ao toque, ao percurso, estabelecendo outras relações com o espaço que aquela obra ocupa.

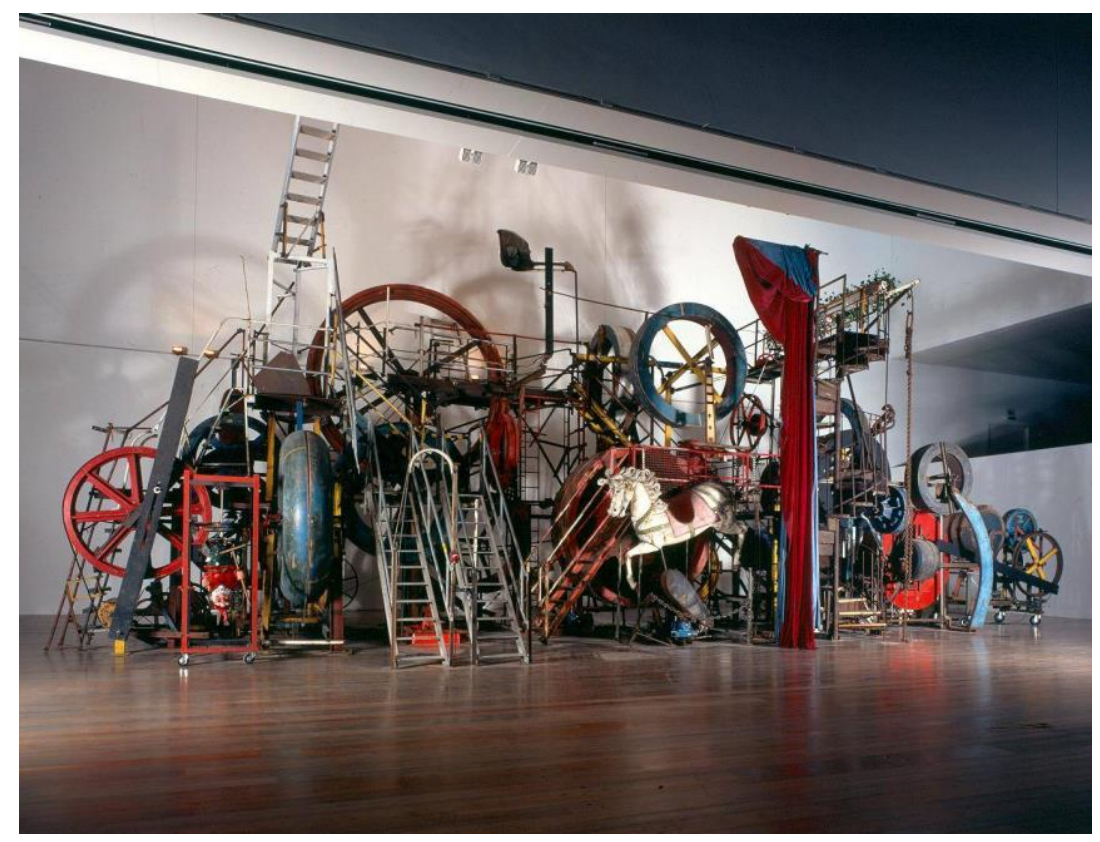

Figura 21: Jean Tinguely. Grosse Méta Maxi-Maxi Utopia, Méta-Harmonie.1987. Imagem presente em:

http://www.tinguely.ch/en/museum_sammlung/sammlung.1980-1991_0113.html

A relação do homem com o espaço é questão primordial em todos os movimentos estéticos surgidos ao longo dos séculos, e a Arquitetura, a arte mais próxima do espaço em termos palpáveis, físicos, também assistiu após a Segunda Guerra Mundial a uma revisão de seus valores até então estabelecidos pelo Movimento Moderno. Arquitetos e teóricos de arquitetura questionavam a relação vigente com o espaço construído e os cânones que guiavam as próprias construções. A chamada "arquitetura neorrealista" esteve presente não só na Itália, onde sua referência nominal havia tomado lugar no campo cinematográfico, mas se espalhou para diversos outros países europeus. Essa estética arquitetônica virava-se contra os parâmetros estabelecidos e tão 
aclamados pelo Movimento Moderno, que colocava todos os homens como seres com necessidades padronizadas e construía para uma forma considerada padrão de se viver, e passava a pautar-se nas necessidades humanas e sociais particulares de cada cidade ou país, inserindo-se na chamada pós-modernidade. Os arquitetos propunham uma arquitetura bastante engajada socialmente, que viesse de encontro às reais necessidades sociais italianas e, ao mesmo tempo, que estabelecessem um vínculo com a história e a identidade do local. Com o título de "arquitetura orgânica", defendida por vários arquitetos e críticos italianos no período, dentre os quais cabe destacar o arquiteto Bruno Zevi e sua obra Por uma Arquitetura Orgânica, de 1945, buscava-se uma arquitetura não vinculada ao autoritarismo dos regimes anteriores, mas pautada na técnica, no meio social e cultural, que retratasse as pessoas que a ocupariam.

Aqui se pode estabelecer um paralelo entre cinema e arquitetura no pósguerra italiano: o neorrealismo de Rosselini, De Sica e Visconti, distanciando-se e contrariando a estética fascista e hollywoodiana cinematográfica, retratou o meio social da forma como eles eram, voltaram-se para os problemas enfrentados, mostrando o cotidiano daqueles cidadãos em meio a uma urbanidade despedaçada, refletiram em seus filmes o espelho daquela realidade incipiente que estava estampada em todos os cantos daquelas cidades destruídas. Evocava-se, através das artes, uma tomada de consciência por parte da sociedade, rumo à reconstrução do país.

A urgência habitacional do pós-guerra viu a construção de inúmeros conjuntos habitacionais em toda a Europa. Na Itália, com os princípios da arquitetura orgânica, propôs-se um espírito de reconstrução da imagem nacional, privilegiando o caráter local, que envolvesse a sociedade e refletisse em suas construções os problemas e as reais necessidades do cidadão, num processo de posicionamento crítico do arquiteto em relação à sociedade, entendendo-a como parte decisiva na estruturação do projeto. De maneira análoga, os cineastas neorrealistas ao colocaram a sociedade como elemento decisivo na estrutura de seus filmes, buscavam uma tomada de consciência

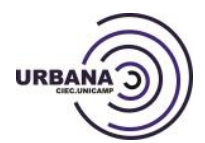


crítica pelo espectador em relação a suas obras, em ordem a instigar uma mudança sócio-político-cultural.

Conclui-se então, a partir dos aspectos desenvolvidos neste texto, a importância do Neorrealismo italiano cinematográfico para a Arte como um todo, sua influência e papel na formação constante da sociedade. Entende-se a tendência e estética neorrealista como precursora e ápice de um pensamento crítico político-social que se mostrou coerente em sua contemporaneidade e continua a despertar as gerações seguintes para a necessidade de uma resistência contra a banalização do intelecto e a dissipação do tempo e espaço nas cidades contemporâneas. Através das relações estabelecidas entre espaço urbano e sociedade nos dois exemplos de obras neorrealistas do cinema italiano, evidencia-se o poder da sétima arte como espelho da realidade e meio para o despertar de um espírito crítico em relação à experiência estética pela sociedade moderna/pós-moderna.

\section{Referências}

AUGUSTO, I. R. A Lição Neo-realista: A breve longa história de um movimento de resistência e libertação do cinema hegemônico. In: 70 ENCONTRO NACIONAL DE HISTÓRIA DA MÍDIA, MÍDIA ALTERNATIVA E ALTERNATIVAS MIDIÁTICAS, 19 a 21 de agosto de 2009, Fortaleza. Disponível em: http://www.ufrgs.br/alcar/encontrosnacionais-1/encontros-nacionais/7o-encontro-2009-1/A\%20Licao\%20Neo-realista.pdf BAUMAN, Z. Modernidade Líquida. Tradução, Plínio Dentzien. Rio de Janeiro: Jorge Zahar, 2001.

CARLOS, C. S. Roma, Cidade Aberta. In: CARLOS, C. S.; GUIMARÃES, P. M., ALPENDRE, S. (Org.) Roma, Cidade Aberta. Coleção Folha Cine Europeu, v.17. São Paulo: Moderna, 2011

FABRIS, M. Neo-Realismo Italiano. In: MASCARELLO, Fernando (Org.). História do Cinema Mundial. Campinas, SP: Papirus, 2008. 3a edição. Pp 191-217.

FABRIS, M. O Neo-Realismo Cinematográfico Italiano: Uma Leitura. São Paulo: Editora da Universidade de São Paulo; FAPESP, 1996.

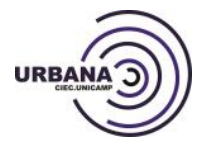


FOLGADO, S. C. M. Saber Ver a Arquitectura Neo-Realista em Portugal. Dissertação de Mestrado Integrado de Arquitetura. Faculdade de Ciências e Tecnologia, Universidade de Coimbra, Departamento de Arquitectura. Coimbra: s.n., julho, 2010.; Disponível em: https://estudogeral.sib.uc.pt/bitstream/10316/14072/1/Saber\%20Ver\%20a\%20Arqui tectura\%20Neo-Realista\%20em\%20Portugal_Disserta\%c3\%a7\%c3\%a3.pdf

KLEIN, Y.; RAYSSE, M. ; ARMAN. Os Novos Realistas. In: FERREIRA, G.; COTRIM, C. (Orgs.) Escritos de Artistas: anos 60/70. Rio de Janeiro: Jorge Zahar, 2009. Pp.53-57. Versão digitalizada disponível em: http://books.google.com.br/books?id=3FuN9BoixJgC\&pg=PA53\&dq=novo + realismo $+j$ ean+tinguely\&hl=pt-

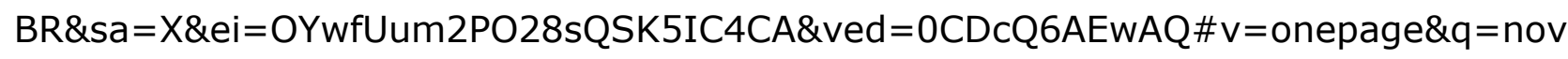
०\%20realismo\%20jean\%20tinguely\&f=false. Acesso 27/08/2013

Ladrões de Bicicleta. Direção: Vittorio de Sica. 1948. Continental, 1948. DVD (88 minutos) NTSC p\&b. Título original: Ladri di Biciclette

LEAL, E. M. "Da porta pra fora": A Constituição de um Problema Social. Pantourbe Revista do Núcleo de Antropologia Urbana da USP. v.1.0, ano 1, jul. 2007. Disponível em: http://www.n-a-u.org/Leal2.html Acesso 28/08/2013

LAIRD, M. Provocador e poeta. Um novo olhar sobre Jean Tinguely. Swissinfo International Service of the Swiss Broadcasting Corporation. 19 de dezembro, 2012. Disponível

em: http://www.swissinfo.ch/por/cultura/Um_novo_olhar_sobre_Jean_Tinguely.html?cid= 33964196. Acesso 29/08/2013

MAGNANI, J. G. C. Festa no pedaço. São Paulo: Brasiliense, 1984.

MASCARELlO, F. História do Cinema Mundial. Campinas: Papirus, 2008. $3^{a}$ edição.

MATTA, R. A casa \& a rua. 5a. Ed. Rio de Janeiro: Rocco, 1997.

Roma, Cidade Aberta. Direção: Roberto Rosselini, 1945. Excelsa Film 2011 Versátil Home Video sob licença Cinecittà Luce S.p.A. DVD (102 minutos) NTSC p\&b. Título Original: Roma, Città Aperta. In: COLEÇÃO FOLHA CINE EUROPEU, v.17

WAGSTAFF, C. Italian Neorealist Cinema. An Aesthetic Approach. Toronto: Univ. of Toronto Press, 2007.

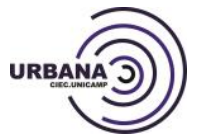
v. 7, n. 10, jan /ago (2015). Dossiê História Urbana: a configuração de um campo conceitual 


\section{Imagens}

Imagem [1] - BACON, F. "Three Studies for Figures at the Base of a Crucifixion". Coleção do Museu Tate Modern. Londres, Inglaterra. Disponível em: http://www.tate.org.uk/art/artworks/bacon-three-studies-for-figures-at-the-base-ofa-crucifixion-n0617.

BACON, F. "Second Version of Triptych" - 1944. Coleção do Museu Tate Modern. Londres, Inglaterra. Disponível em: http://www.tate.org.uk/art/artworks/baconsecond-version-of-triptych-1944-t05858

Imagem [2] a [20] - Frames retirados a partir dos filmes "Roma Cidade Aberta" (Roma, Cidade Aberta. Direção: Roberto Rosselini, 1945. Excelsa Film 2011 Versátil Home Video sob licença Cinecittà Luce S.p.A. DVD (102 minutos) NTSC p\&b. Título Original: Roma, Città Aperta. In: COLEÇÃO FOLHA CINE EUROPEU, v.17) e "Ladrões de Bicicleta" (Ladrões de Bicicleta. Direção: Vittorio de Sica. 1948. Continental, 1948. DVD (88 minutos) NTSC p\&b. Título original: Ladri di Biciclette)

Imagem [21] - TINGUELY, ]. "Grosse Méta Maxi-Maxi Utopia, Méta-Harmonie", 1987. Coleção do Museum Tinguely. Basel, Suíça. Disponível em: http://www.tinguely.ch/en/museum_sammlung/sammlung.1980-1991_0113.html 